\title{
Magnetic Resonance-Guided Focused Ultrasound : Current Status and Future Perspectives in Thermal Ablation and Blood-Brain Barrier Opening
}

\author{
Eun Jung Lee, M.D., ${ }^{1}$ Anton Fomenko, M.D., Andres M. Lozano, OC, M.D., Ph.D., FRCSC, FRSC ${ }^{1,2}$ \\ Toronto Western Research Institute, 'University Health Network, Toronto, Canada \\ Division of Neurosurgery, ${ }^{2}$ Department of Surgery, Toronto Western Hospital, University of Toronto, Toronto, Canada
}

Magnetic resonance-guided focused ultrasound (MRgFUS) is an emerging new technology with considerable potential to treat various neurological diseases. With refinement of ultrasound transducer technology and integration with magnetic resonance imaging guidance, transcranial sonication of precise cerebral targets has become a therapeutic option. Intensity is a key determinant of ultrasound effects. High-intensity focused ultrasound can produce targeted lesions via thermal ablation of tissue. MRgFUS-mediated stereotactic ablation is non-invasive, incision-free, and confers immediate therapeutic effects. Since the US Food and Drug Administration approval of MRgFUS in 2016 for unilateral thalamotomy in medication-refractory essential tremor, studies on novel indications such as Parkinson's disease, psychiatric disease, and brain tumors are underway. MRgFUS is also used in the context of blood-brain barrier (BBB) opening at low intensities, in combination with intravenously-administered microbubbles. Preclinical studies show that MRgFUS-mediated BBB opening safely enhances the delivery of targeted chemotherapeutic agents to the brain and improves tumor control as well as survival. In addition, BBB opening has been shown to activate the innate immune system in animal models of Alzheimer's disease. Amyloid plaque clearance and promotion of neurogenesis in these studies suggest that MRgFUS-mediated BBB opening may be a new paradigm for neurodegenerative disease treatment in the future. Here, we review the current status of preclinical and clinical trials of MRgFUS-mediated thermal ablation and BBB opening, described their mechanisms of action, and discuss future prospects.

Key Words : Alzheimer disease · Blood-brain barrier · Essential tremor · High-intensity focused ultrasound ablation.

\section{INTRODUCTION}

Magnetic resonance-guided focused ultrasound (MRgFUS) is an emerging technique that uses acoustic energy delivered through the skull to treat intracranial diseases. In the early 1950s, William Fry and colleagues first developed high-inten- sity focused ultrasound (HIFU) as a neurosurgical tool to treat symptoms associated with Parkinson's disease ${ }^{29,42-45,83)}$. Through early explorations with the feline brain, they discovered that high-intensity ultrasound could be precisely focused to create a distinct, thermal coagulative lesion in the brain without damaging the intervening tissue ${ }^{42,83)}$. However, at that

- Received : September 4, 2018 •Revised : October 8, 2018 •Accepted : November 13, 2018

- Address for reprints : Andres M. Lozano, OC, M.D., Ph.D., FRCSC, FRSC

Division of Neurosurgery, Department of Surgery, Toronto Western Hospital, 399 Bathurst Street, Toronto, ON M5T 2S8, Canada

Tel : +1-416-603-6200, Fax : +1-416-603-5298, E-mail : Andres.Lozano@uhnresearch.ca

This is an Open Access article distributed under the terms of the Creative Commons Attribution Non-Commercial License (http://creativecommons.org/licenses/by-nc/4.0) which permits unrestricted non-commercial use, distribution, and reproduction in any medium, provided the original work is properly cited. 
time, widespread clinical application of HIFU as neurotherapeutic tool was limited, because ultrasound transducers were insufficiently powered to penetrate the skull and thus craniectomy was required to avoid absorption and reflection of ultrasonic energy at the bony interface ${ }^{29,39,43-45,82)}$. In the late 1990s, a completely non-invasive FUS treatment was realized consisting of a head-mounted set of phase-array transducers arrays operating under real-time magnetic resonance imaging (MRI) guidance $^{49,82}$. Software was also incorporated into the device to rectify phase aberrations due to skull thickness, based on pre-obtained computed tomography scans, enabling multiple ultrasonic waves to converge at single focus ${ }^{26,39)}$. Furthermore, simultaneous MR thermometry provided real-time temperature monitoring, enabling confirmation that the target zone has been reached with the proper thermal dose ${ }^{39,49)}$. To couple energy delivery to the scalp, cooled degassed water $\left(15-20^{\circ} \mathrm{C}\right)$ was circulated in a silicone rubber diaphragm tightly placed around the patient's head ${ }^{39)}$. In 2016, the US Food and Drug Administration (FDA) approved HIFU thalamotomy as a treatment for medication-refractory essential tremor (ET), and ablative HIFU is now being investigated for the treatment of movement disorders such as Parkinson's disease (PD), and in an ever-widening set of neurological diseases including psychiatric disease and brain tumors ${ }^{20,34,54,72,79,84)}$. Meanwhile, blood-brain barrier (BBB) opening by delivering pulsed ultrasound to microbubble-enriched cerebral vasculature has been under active investigation in the hope of enhancing drug delivery to the brain for the treatment of intracranial disease $e^{14,24,36)}$. Here we review the current status and prospects of MRgFUS clinical applications in neurosurgical field in terms of thermal ablation and BBB opening and discuss the direction and challenges of MRgFUS research in the future.

\section{THERAPEUTIC MECHANISMS OF ULTRASOUND IN THE CENTRAL NERVOUS SYSTEM}

Ultrasound is defined as an acoustic wave with fundamental frequency above the upper limit of human hearing $(>20$ $\mathrm{kHz}$ ). Ultrasound frequencies for medical imaging range between 2-20 MHz, while those for therapeutic applications are lower $(0.2-2 \mathrm{MHz})^{106,109,110)}$. Ultrasound used in treatment is categorized into two types based on its intensity, which is defined as the total power delivered divided by the beam area at the focal region $\left(\mathrm{W} / \mathrm{cm}^{2}\right)$. Depending on the intensity, ultrasound has different biophysical actions on tissues ${ }^{112,118)}$. HIFU requires an intensity greater than $1000 \mathrm{~W} / \mathrm{cm}^{2}$, which induces thermal ablation of tissue at the focal region. HIFU in continuous mode induces frictional energy in the target area so that the target tissue is heated, causing protein denaturation, DNA fragmentation, coagulative necrosis, and cellular death ${ }^{1,11,28,322}$. Meanwhile, intervening tissues such as scalp, skull, cerebrospinal fluid, and superficial structures receive unfocused ultrasonic waves with intensities lower than the heating threshold of tissues ${ }^{39,47,61,92)}$. HIFU delivered at $\sim 300 \mathrm{~W} / \mathrm{cm}^{2}$ has also been shown to suppress neuronal activity by disrupting synaptic contacts ${ }^{11,118)}$. However, as HIFU at various intensities can eventually result in permanent tissue damage, its application for neuromodulation is suboptimal ${ }^{29)}$. In contrast, lowintensity focused ultrasound (LIFU) has been shown to modulate activity of neurons and glial cells, and is typically pulsed, with FDA limits of time-averaged intensities $\leq 94 \mathrm{~mW} / \mathrm{cm}^{2}$ and pulse-averaged intensities $<190 \mathrm{~W} / \mathrm{cm}^{233,40,88)}$. Depending on key pulsing parameters such as pulse repetition frequency and duty cycle, pulsed LIFU can either suppress or evoke neuronal activity. One proposed neurostimulatory mechanism is that acoustic radiation forces and pressure mechanically stretch the lipid bilayer of neurons and thereby open voltage-gated ion channels with mechanosensitive properties, including $\mathrm{Na}^{+}$, $\mathrm{Ca}^{2+}$, and $\mathrm{K}^{+}$channels, which in turn results in depolarization and neuronal excitation ${ }^{55,86,19)}$ (Fig. 1). An additional potential theory is that alterations in the membrane permeability to ions triggered by the mechanical force of LIFU is speculated to result in local membrane depolarization which in turn stimulates voltage-gated ion channels ${ }^{118,119)}$. Neuroinhibitory mechanisms of LIFU are also thought to be stretch-mediated, but the excitatory or inhibitory effects of LIFU on neurons differs depending on the ultrasound parameters ${ }^{15}$. These neuromodulatory properties of pulsed LIFU makes FUS appealing as a non-invasive neuromodulation method ${ }^{40)}$. Although several non-invasive neuromodulating technologies such as repetitive transcranial magnetic stimulation (rTMS) and transcranial direct current stimulation have been employed, they suffer from drawbacks such as poor spatial resolution and poor depth penetration ${ }^{15,68)}$. Conversely, FUS has high spatial specificity, with a focus of a few millimeters in diameter, and is able to reach deep brain targets due to advances in transducer focusing technology. In addition, unlike rTMS, the si- 


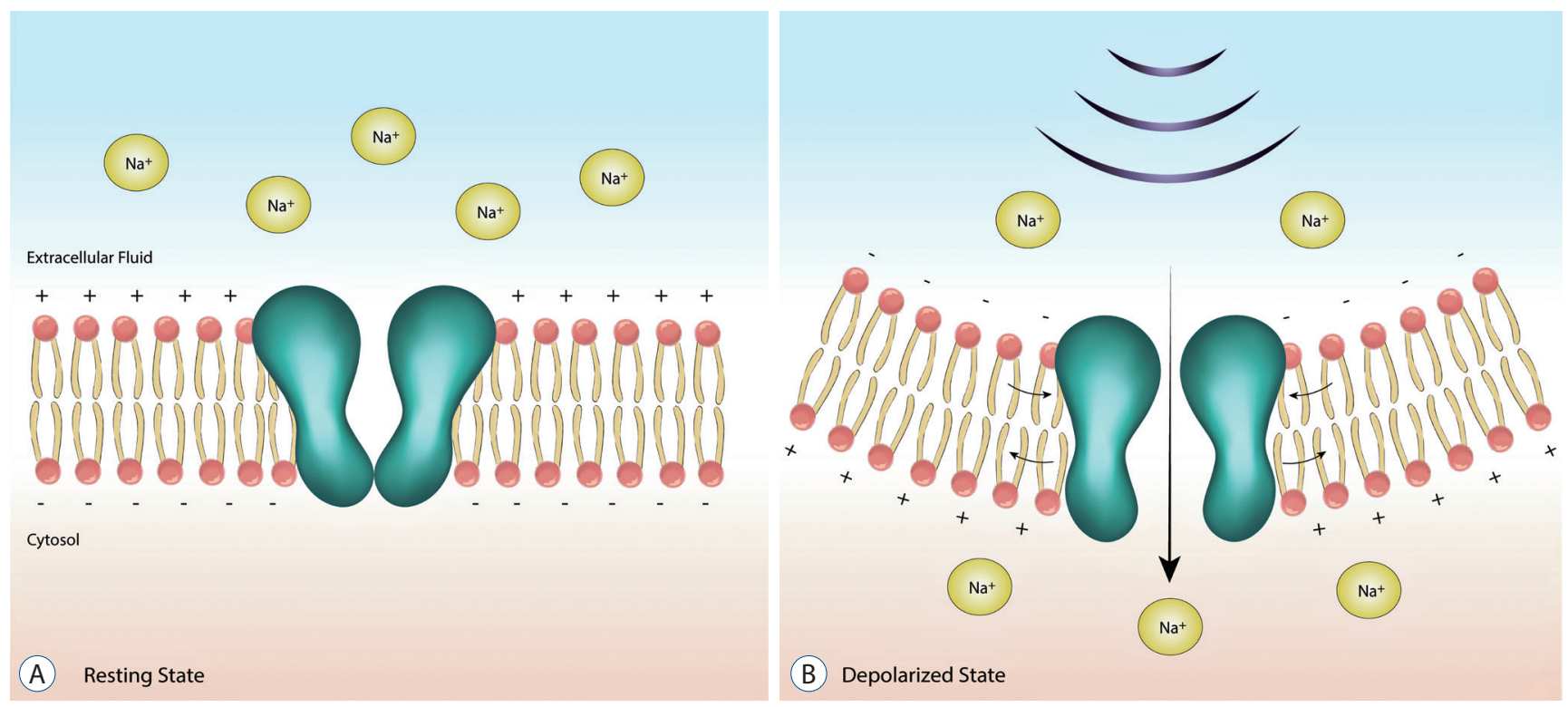

Fig. 1. Schematic depicting proposed pulsed LIFU neuromodulation mechanism. A : Resting state of neuron without ultrasound. B : Depolarized state with ultrasound. The mechanical force of ultrasound wave changes neuronal lipid bilayers tension. Voltage-gated ion channels, including $\mathrm{Na}^{+}, \mathrm{Ca}^{2+}, \mathrm{and}$ $\mathrm{K}^{+}$channels, with mechanosensitive properties, open in response to pulsed LIFU, which leads to depolarization and generation of action potentials, eventually stimulating neurons. Here, $\mathrm{Na}^{+}$channels are depicted as an example. LIFU : low-intensity focused ultrasound.

multaneous use of FUS and functional MRI is feasible, enabling high-spatial resolution brain mapping ${ }^{15,68}$. Meanwhile, at higher energies, pulsed LIFU has the important characteristic of being capable to produce stable oscillation of microbubbles, which transiently opens the BBB by separating the endothelial tight junction, enhancing the localized delivery of therapeutic agents including antibodies, growth factors, nanoparticles, nucleic acid, viral vectors, and cells to the brain $^{39,65,105)}$ (Fig. 2). Initially, HIFU had been applied for BBB opening, however, high intensities risk giving rise to thermal coagulation of tissue and undesirable inertial cavitation, which result in permanent tissue damage or gross hemorrhage ${ }^{120,121)}$. To avoid these adverse effects, in 2001, Hynynen et al. ${ }^{50)}$ applied LIFU, instead of HIFU, in conjunction with intravenously administered preformed microbubbles for BBB opening. As preformed microbubbles pass through the ultrasound field, they oscillate at the same frequency as ultrasound waves, resulting in stable contraction and expansion. This stable cavitation of microbubbles is thought to concentrate the ultrasonic energy and impart mechanical force to the cerebral vasculature, enabling transient, safe, and reproducible BBB disruption at low frequencies ${ }^{50,51,81}$. Ultrasound produces periodic pressure variation in biological tissues as it transmits, triggering the formation and oscillation of small gas filled cavities (i.e., microbubbles) in the tissue fluids ${ }^{91,118)}$. Two types of cavitation are generated by the ultrasound wave depending on its intensity (Fig. 3). First, inertial cavitation is created when microbubbles exposed to HIFU, violently collapse after expanding nonlinearly ${ }^{118)}$. Inertial cavitation can damage tissues by inducing extremely high temperatures, jet streams, and high concentration of free radicals in the tissue $e^{29,106,110)}$. A second type of stable cavitation achieved when the microbubbles are subjected to pulsed LIFU, is more benign since the bubbles do not violently explode or collapse ${ }^{15,100,118)}$.

\section{CLINICAL APPLICATION OF HIFU ON THERMAL ALBALTION}

\section{Stereotatic lesioning}

MRgFUS has been investigated most commonly in movement disorders. Lesioning via stereotactic radiofrequency (RF) ablation has effectively alleviated movement disorder symptoms in ET, PD, and dystonia. Therefore, it was thought that lesioning using HIFU would work in a similar way in these diseases. Contrary to conventional RF lesioning methods, lesioning via MRgFUS is noninvasive, that is, no incision, no burr hole trephination, and no electrode insertion are re- 


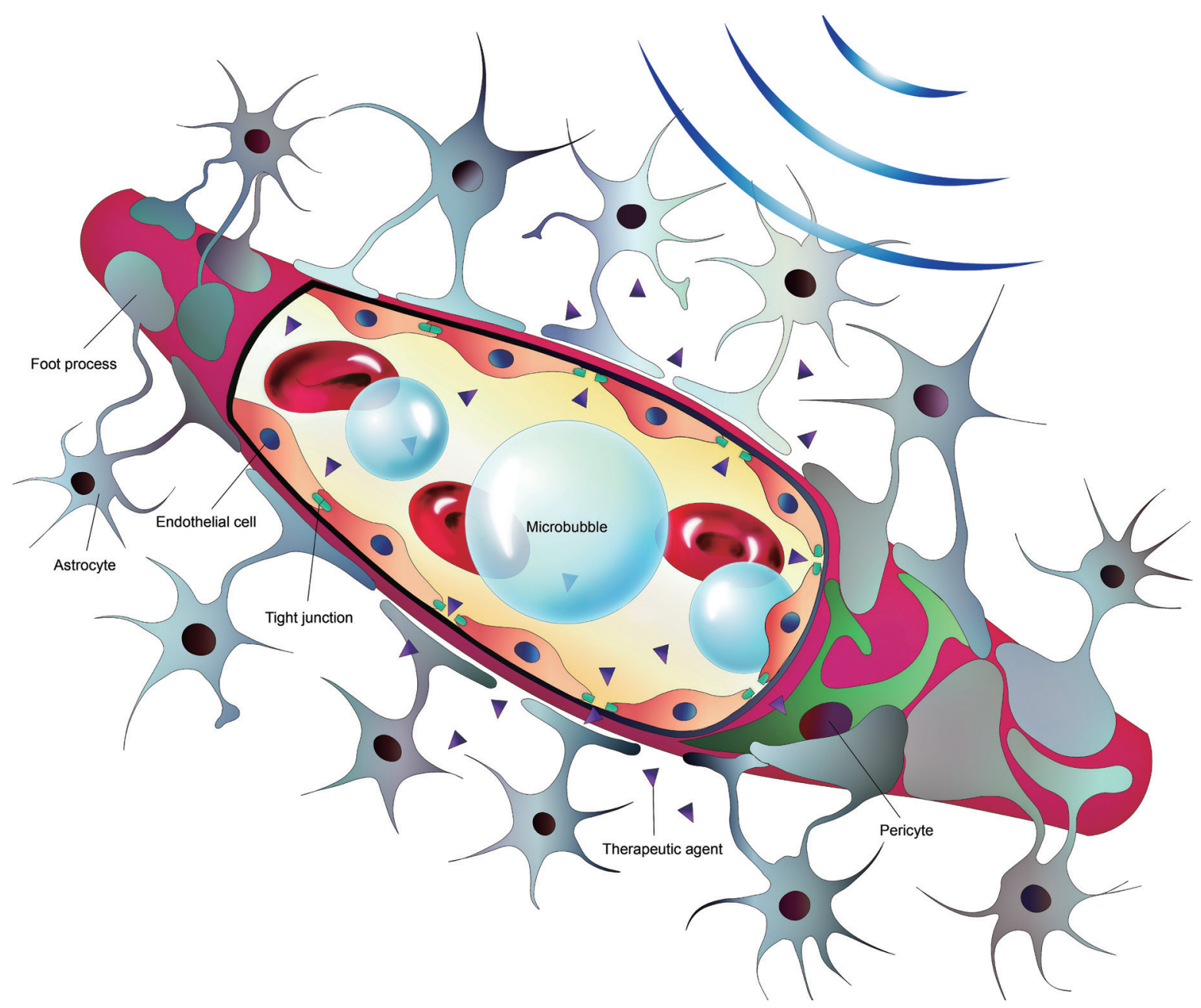

Fig. 2. Schematic illustration of transient BBB opening. MRgFUS in conjunction with microbubbles leads to open the BBB by separating the endothelial tight junction, allowing enhanced delivery of therapeutic agents. BBB : blood-brain barrier, MRgFUS : magnetic resonance-guided focused ultrasound.

quired. Moreover, as stereotactic targets of movement disorder are located near the center of the skull, it is feasible to make a discrete lesion at the target while minimizing thermal damage to the overlying skull and scalp. In addition, since the procedure is performed in awake patients and in a stepwise fashion, immediate clinical feedback is available from the patients, encouraging the application of MRgFUS to movement disorders. Since MRgFUS unilateral thalamotomy in medication-refractory ET patients was approved by FDA in 2016, its application has bloomed, and clinical indications have expanded. MRgFUS uses a protocol for lesioning which is transferable across its many clinical indications. First, escalating doses of lowpower sonication are applied to raise target temperatures to around $45^{\circ} \mathrm{C}$, below the threshold leading to coagulation necrosis. At this time, radiological evaluation of thermal lesion- ing location and clinical evaluation for safety is performed. After accuracy at the desired target is determined, several high-power sonications are applied under the guidance of MR thermometry, gradually escalating the acoustic power and energy until the temperature at the target reaches $55-60^{\circ} \mathrm{C}^{72,76)}$. MRgFUS parameters across various intracranial applications are summarized in Table 1.

\section{Essential tremor}

ET is the most common movement disorder affecting $4 \%$ of the population over 40 years old, characterized by postural and intentional tremors at $8-12 \mathrm{~Hz}^{34,82}$. The primary treatment for ET is medication such as propranolol and primidone, but surgical treatment targeting the ventral intermediate nucleus (Vim) of the thalamus may be considered in patients 


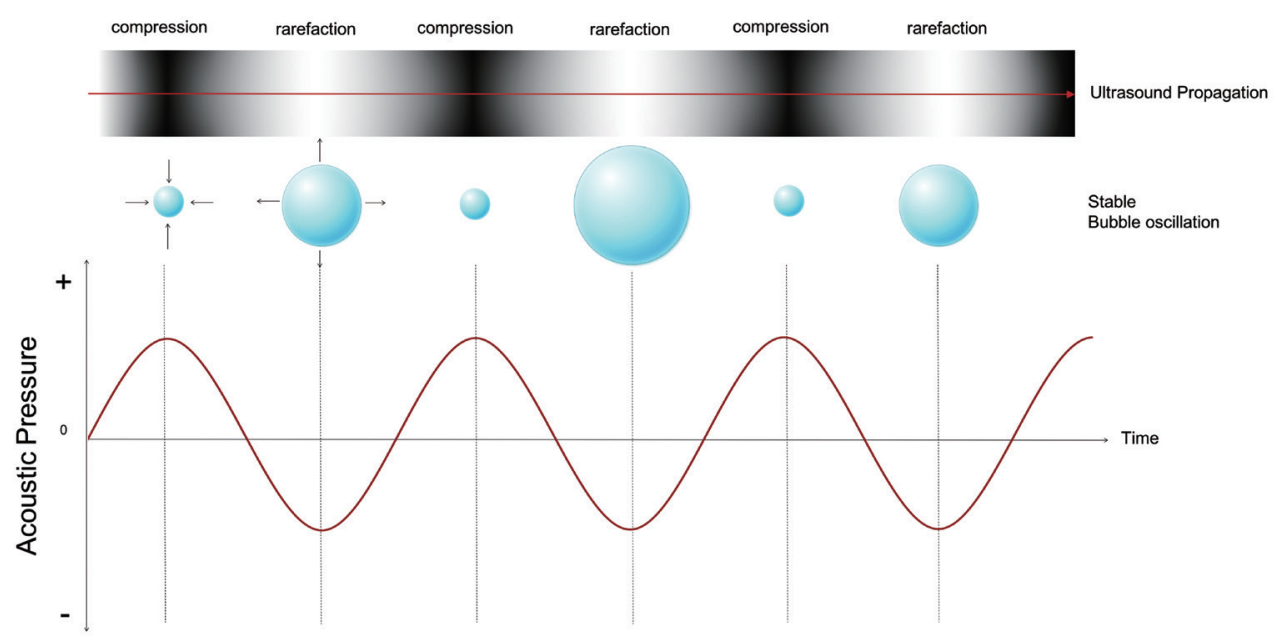

(A)

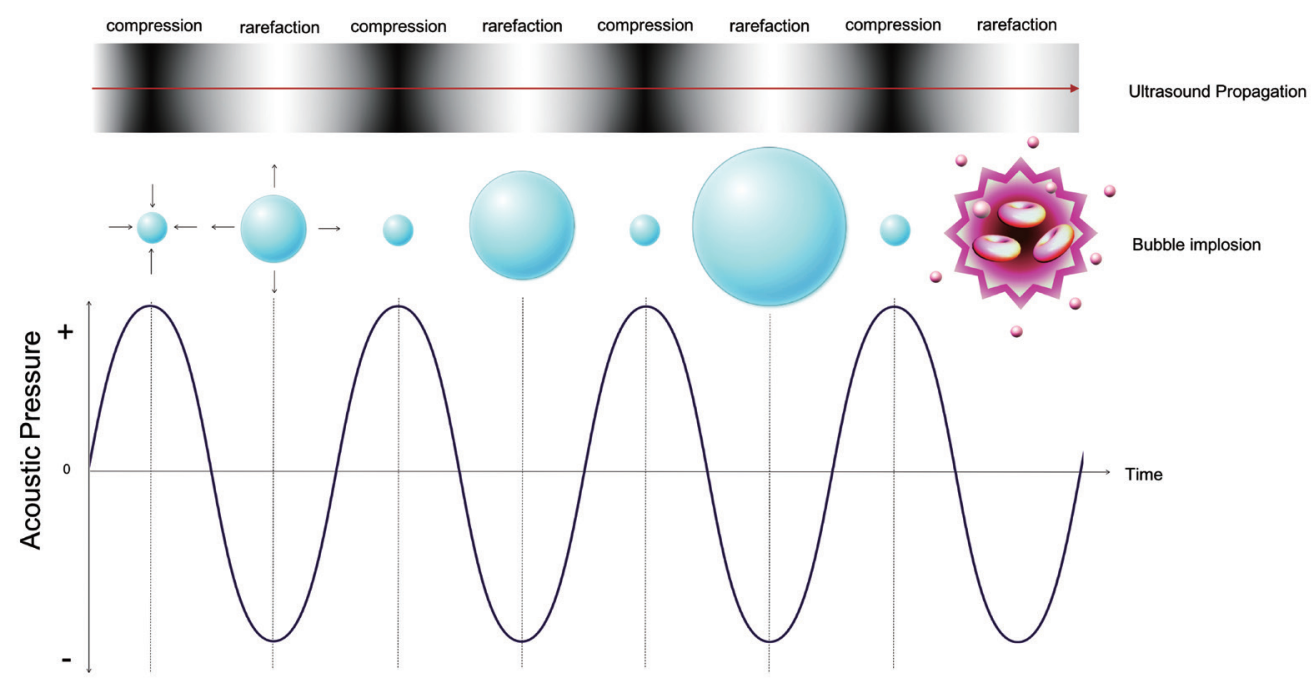

(B)

Fig. 3. A : Schematic illustration of stable cavitation. As the acoustic wave propagates longitudinally, it alternates between compression and expansion, with changing acoustic pressures along the sinusoidal curve. When microbubbles are subjected to pressures below the inertial cavitation threshold, they contract during compression and expand during rarefaction, resulting in stable oscillation. $\mathrm{B}$ : With ultrasonic pressure above the inertial cavitation threshold, microbubbles initially oscillate but eventually implode at rarefaction pressure.

who are refractory or intolerant of medication. RF ablation, radiosurgery, or deep brain stimulation (DBS) are options that may be considered for the patients ${ }^{82,89,127)}$. The first two pilot studies of MRgFUS thalamotomy were published in 2013. One proof of concept study, in which four ET patients were enrolled, showed favorable outcome of $81.3 \%$ reduction of tremor in the dominant hand and $51.1 \%$ reduction in functional disability, as measured on the Clinical Rating Scale for Tremor (CRST) score, at 3 months after surgery ${ }^{72)}$. Another study was performed in 15 patients and also demonstrated promising results of significant improvement of the contralateral hand tremor by $75 \%(p=0.001)$ and functional disability related to tremor by $85 \%(p=0.001)$ at 12 months after surgery ${ }^{34)}$. A subsequent randomized trial in 76 patients (20 sham-treated pa- 
Table 1. MRgHIFU parameters in various intracranial disease applications

\begin{tabular}{|c|c|c|c|c|c|c|c|c|}
\hline \multirow[b]{2}{*}{ Study } & \multirow[b]{2}{*}{ Application } & \multirow[b]{2}{*}{ Disease } & \multirow{2}{*}{$\begin{array}{c}\text { Number } \\
\text { of } \\
\text { patients }\end{array}$} & \multicolumn{4}{|c|}{ Parameters of sonication } & \multirow{2}{*}{$\begin{array}{l}\text { Max temp } \\
\left({ }^{\circ} \mathrm{C}\right) \text { at focus }\end{array}$} \\
\hline & & & & Frequency & $\begin{array}{l}\text { Number of } \\
\text { Sonications }\end{array}$ & $\begin{array}{c}\text { Duration } \\
\text { per sonication }\end{array}$ & $\begin{array}{l}\text { Max acoustic power or } \\
\text { energy per sonication }\end{array}$ & \\
\hline Elias et al. ${ }^{34)}$ (2013) & Vim thalamotomy & ET & 15 & $650 \mathrm{kHz}$ & $18(11-26)$ & 10-20 seconds & 10320 J (6500-20800) & $58.4(54-63)$ \\
\hline $\begin{array}{l}\text { Chang et al. } \\
\text { (2018) }\end{array}$ & Vim thalamotomy & ET & 76 & $650 \mathrm{kHz}$ & 18.5 & $10-20$ seconds & $14497 \mathrm{~J}(3500-34860)$ & $55.6 \pm 2.3$ \\
\hline $\begin{array}{l}\text { Zaaroor et al. } \\
\text { (2018) }\end{array}$ & Vim thalamotomy & $\begin{array}{l}\text { ET or } \\
\text { TDPD }\end{array}$ & 30 & $650 \mathrm{kHz}$ & $21(14-45)$ & $13-24$ & 12500J (5850-23040) & $56.5(55-60)$ \\
\hline Bond et al. ${ }^{10)}(2017)$ & ) Vim thalamotomy & TDPD & 27 & $710 \mathrm{kHz}$ & 13.2 & NA & $8977 \mathrm{~J}\left(>50^{\circ} \mathrm{C}\right)$ & 52.4 \\
\hline $\begin{array}{l}\text { Magara et al. } \\
(2014)\end{array}$ & $\begin{array}{l}\text { Pallidothalamic } \\
\text { tractotomy }\end{array}$ & PD & 13 & $710 \mathrm{kHz}$ & 4-5 at peak ${ }^{\circ} \mathrm{C}$ & $10-21$ & $1200 \mathrm{~W} / 20400 \mathrm{~J}$ & $56.2(52-59)$ \\
\hline $\begin{array}{l}\text { Martínez- } \\
\text { Fernández et al. }{ }^{77)} \\
\text { (2018) }\end{array}$ & Subthalamotomy & PD & 10 & NA & $\begin{array}{c}23(16-39) \text { in } \\
\text { total } \\
8(4-12)>55^{\circ} \mathrm{C}\end{array}$ & $\begin{array}{l}144-379 \\
\text { seconds in total }\end{array}$ & $14624 \mathrm{~J}(7200-36680)$ & 57 \\
\hline Kim et al. ${ }^{63)}(2018)$ & $\begin{array}{l}\text { Bilateral } \\
\text { capsulotomy }\end{array}$ & OCD & 11 & $650 \mathrm{kHz}$ & $(23-37)$ & $\begin{array}{c}>3 \text { seconds at a } \\
\text { peak }{ }^{\circ} \mathrm{C}\end{array}$ & NA & $51-65$ \\
\hline $\begin{array}{l}\text { Jeanmonod et } \\
\text { al. }^{54)}(2012)\end{array}$ & $\begin{array}{l}\text { Central lateral } \\
\text { thalamotomy }\end{array}$ & CNP & 12 & $650 \mathrm{kHz}$ & NA & $10-20$ seconds & $800-1200$ W/12000 J & $51-64$ \\
\hline $\begin{array}{l}\text { McDannold et al. }{ }^{79)} \\
\text { (2010) }\end{array}$ & Tumor ablation & GBM & 3 & $670 \mathrm{kHz}$ & 12,16 , and 17 & 20 seconds & $\begin{array}{l}\text { 650W (patient } 1 \text { and 3) } \\
800 \text { W (patients 2) }\end{array}$ & 42,51 , and 48 \\
\hline $\begin{array}{l}\text { Coluccia et al. }^{27)} \\
(2014)\end{array}$ & Tumor ablation & $\begin{array}{l}\text { Recurrent } \\
\text { GBM }\end{array}$ & 1 & $650 \mathrm{kHz}$ & 25 & $10-25$ seconds & 150-950 W/19950 J & 65 \\
\hline $\begin{array}{l}\text { Monteith et al. }{ }^{84)} \\
\text { (2013) }\end{array}$ & $\begin{array}{l}\text { Thrombolysis } \\
\text { Laboratory }\end{array}$ & $\mathrm{ICH}$ & $\begin{array}{l}5 \text { swine; } 5 \\
\text { cadavers }\end{array}$ & $230 \mathrm{kHz}$ & $(2-3)$ & 30 seconds & $\begin{array}{l}1500 \text { W for swine with skull } \\
750 \text { W for swine without skull } \\
3950 \text { W for cadavers }\end{array}$ & $6(4-11)$ \\
\hline Alkins et al. ${ }^{4)}$ (2013) & $\begin{array}{l}\text { CSF diversion } \\
\text { Laboratory }\end{array}$ & $\mathrm{OHCP}$ & 9 swine & $\begin{array}{l}650 \mathrm{kHz} \\
230 \mathrm{kHz}\end{array}$ & NA & $0.1-5$ seconds & $\begin{array}{c}1000-2200 \text { W for } 650 \mathrm{kHz} \\
2900 \text { W for } 230 \mathrm{kHz}\end{array}$ & No significant \\
\hline
\end{tabular}

Values are presented as mean (range). MRgHIFU : magnetic resonance-guided focused ultrasound, Vim : ventral intermediate nucleus, ET : essential tremor, TDPD : tremor-dominant Parkinson's disease, NA : not applicable, PD : Parkinson's disease, OCD : obsessive-compulsive disorder, CNP : chronic neuropathic pain, GBM : glioblastoma multiforme, ICH : intracerebral hemorrhage, CSF : cerebrospinal fluid, oHCP : obstructive hydrocephalus

tients) with ET confirmed the efficacy of MRgFUS thalamotomy with improvement of hand tremor score by $47 \%$ and by $62 \%$ reduction in disability score at 3 months ${ }^{35)}$. Recently, the same group has reported the long-term robustness of MRgFUS thalamotomy ${ }^{19)}$. At 2 years after surgery (67 patients), the mean hand tremor and functional disability scores improved by $56 \%$ and $60 \%$, respectively, with two patients reporting complete resolution of hand tremor. Commonly reported acute adverse effects included numbness/paresthesia (38\%), taste disturbances, headache, and ataxia ${ }^{21,58,97,128)}$. The vast majority of side effects recovered within 3 months after treatment ${ }^{21,48,58,128)}$. Long-term side effects persisting at 2 years included gait disturbance, dysgeusia, dysmetria, muscle weakness, and dizziness, while all events were reported mild to moderate ${ }^{19)}$. The adjustable and titratable properties of DBS have certain advantages over lesioning surgery ${ }^{111)}$. However, DBS is an invasive procedure that can be associated with infection $(1-3 \%)$ or hemorrhage $(0.5-2.0 \%)$, and hardware problems including electrode migration, fracture (1-3\%), and malfunction $(1-3 \%)^{38,39,96,108)}$. Also, DBS patients with primary cells require periodic replacement of the implanted pulse generator when the batteries are depleted. GammaKnife radiosurgery (GKRS) is another non-invasive technique for lesioning but can be associated with some unpredictability of the response and delayed effects of radiation, often requiring weeks to months to detect a clinical benefit ${ }^{39,82)}$. Moreover, since it is not possible to monitor the patients' clinical symptoms during the procedure, determining an optimized target with GKRS can be challenging. Several clinical trials are underway to further evaluate the effectiveness and safety of MRgFUS 
unilateral thalamotomy (NCT01827904, NCT02289560, NCT03253991). The current status of clinical investigation of MRgFUS in various intracranial diseases is presented in Table 2.

\section{Parkinson's disease}

$\mathrm{PD}$ is another main indication for MRgFUS. The success of MRgFUS-mediated Vim thalamotomy trials in ET patients inspired investigators to target the Vim in tremor-dominant PD patients ${ }^{37,102,128)}$. Zaaroor et al. ${ }^{128)}$ reported that in 9 tremordominant PD patients undergoing MRgFUS Vim thalamotomy, the total motor Unified Parkinson's Disease Rating Scale (UPDRS) score improved by $46.2 \%$ at 6 months after surgery, while resting and postural tremors (assessed by the item 20 and 21 of UPDRS) alleviated by $90 \%$ and $80 \%$, respectively
(NCT03300193). A randomized double-blind sham-controlled study in 27 patients (seven sham-treated patients) followed up to 1 year also demonstrated long-term efficacy of MRgFUS Vim thalamotomy in tremor-dominant PD (NCT01772693) ${ }^{10)}$. On medication, the CRST score improved by $62 \%$ following MRgFUS thalamotomy versus $22 \%$ after sham procedure at 3 months after surgery, while motor UPDRS score improved by $35 \%$ versus $4 \%$ after MRgFUS thalamotomy and sham procedure, respectively, at 3 months after surgery. At 1 year, $65 \%$ of patients (13 out of 20) had a positive outcome, defined as at least $50 \%$ reduction in the on-medication hand tremor subscores of the CRST from a baseline. At 1-year follow-up, paresthesia remained in $19 \%$ of patients, while $4 \%$ reported persistent ataxia. Further long-term studies are needed to determine

Table 2. Current status of clinical trials of MRgHIFU treatment in neurological diseases

\begin{tabular}{|c|c|c|c|c|}
\hline Indication & Stage & Disease subtype & Target & Status \\
\hline Essential tremor & Phase II & & Unilateral Vim & $\begin{array}{l}\text { One phase II trial published (NCT01827904) other phase II trials } \\
\text { currently being conducted (NCT01827904, NCT02289560) and } \\
\text { recruiting patients (NCT03253991) }\end{array}$ \\
\hline \multirow[t]{3}{*}{ Parkinson's disease } & Phase I & Tremor-dominant & Unilateral Vim & $\begin{array}{l}\text { Several trials published (NCT02252380 } \\
\text { NCT01772693 }{ }^{30)} \text { ) NCT03300193 }\end{array}$ \\
\hline & & $\begin{array}{l}\text { Levodopa-induced } \\
\text { dyskinesia }\end{array}$ & Unilateral GPi & $\begin{array}{l}\text { Currently conducting trials and recruiting patients (NCT02347254, } \\
\text { NCT02003248, NCT02263885, NCT03319485) }\end{array}$ \\
\hline & & Akinesia-dominant & Unilateral STN & $\begin{array}{l}\text { One phase I trial published (NCT02912871), currently conducting } \\
\text { trials (NCT02246374) and recruiting patients (NCT03454425) }\end{array}$ \\
\hline \multirow[t]{2}{*}{ Psychiatric disease } & Phase I & $\begin{array}{l}\text { Major depressive } \\
\text { disorder }\end{array}$ & Bilateral ALIC & $\begin{array}{l}\text { Case report published and recruiting patients (NCT03421574, } \\
\text { NCT02348411) }\end{array}$ \\
\hline & & $\begin{array}{l}\text { Obsessive-compulsive } \\
\text { disorder }\end{array}$ & Bilateral ALIC & $\begin{array}{l}\text { One phase I trial published currently conducting trials } \\
\text { (NCT01986296) and recruiting patients (NCT03156335) }\end{array}$ \\
\hline \multirow[t]{2}{*}{ Pain syndrome } & Phase I & Neuropathic pain & $\begin{array}{l}\text { Central lateral } \\
\text { thalamic nucleus }\end{array}$ & $\begin{array}{l}\text { One published }{ }^{54)} \text { and continuing to recruit patients } \\
\text { (NCT03255395) }\end{array}$ \\
\hline & & $\begin{array}{l}\text { Trigeminal neuropathic } \\
\text { pain }\end{array}$ & $\begin{array}{l}\text { Bilateral medial } \\
\text { thalamic nucleus }\end{array}$ & Currently recruiting patients (NCT03309813) \\
\hline \multirow[t]{2}{*}{ Epilepsy } & Phase I & $\begin{array}{l}\text { Secondary epilepsy due } \\
\text { to subcortical lesion }\end{array}$ & Subcortical lesion & Currently recruiting patients (NCT02804230) \\
\hline & & Generalized & $\begin{array}{l}\text { Anterior thalamic } \\
\text { nucleus }\end{array}$ & Currently recruiting patients (NCT03417297) \\
\hline \multirow[t]{2}{*}{ Brain tumor ablation } & Phase I & Malignant & & $\begin{array}{l}\text { One study completed (NCT01698437) and now recruiting } \\
\text { patients (NCT01473485, CT00147056) }\end{array}$ \\
\hline & & Benign & Centrally located & Now recruiting patients (NCT03028246) \\
\hline $\begin{array}{l}\text { Thrombolysis/ } \\
\text { intracerebral hemorrhage }\end{array}$ & Preclinical & & & $\begin{array}{l}\text { Swine and cadaveric models demonstrated feasibility of } \mathrm{ICH} \\
\text { liquefaction }{ }^{85}\end{array}$ \\
\hline CSF diversion & Preclinical & & $\begin{array}{l}\text { Floor of third } \\
\text { ventricle }\end{array}$ & $\begin{array}{l}\text { Providing proof-of-principle of MRgHIFUS- mediated third } \\
\text { ventriculostomy }{ }^{4)}\end{array}$ \\
\hline
\end{tabular}

MRgHIFU : magnetic resonance-guided focused ultrasound, Vim : ventral intermediate nucleus, GPi : globus pallidus interna, STN : subthalamic nucleus, ALIC : anterior limb of internal capsule, ICH : intracerebral hemorrhage, CSF : cerebrospinal fluid 
whether MRgFUS thalamotomy for PD has lasting effectiveness and if patient side effects eventually resolve. The globus pallidus interna can be another important target for MRgFUS. In an early report of MRgFUS unilateral pallidotomy in a PD patient suffering from severe dyskinesias, the motor UPDRS score in on-medication state was reduced by $60 \%$ at 6 months after surgery, whereas score in the off-medication state was reduced by $55 \%{ }^{87)}$. The unified dyskinesia rating scale score was also significantly improved by $70 \%$ at 6 months postoperatively. Several clinical trials of MRgFUS unilateral pallidotomy are in progress (NCT02003248, NCT02263885, NCT02347254, NCT03319485). Because of the high incidence of adverse effects with bilateral lesions, MRgFUS pallidotomy has been limited in only one hemisphere ${ }^{52,107)}$. Meanwhile, despite the subthalamic nucleus (STN) is a well-established DBS target, stereotactic lesioning surgery targeting the STN had been limited because of concerns about incidence of postoperative involuntary movement such as hemichorea and hemiballismus, which were reported as high as $15 \%{ }^{6,39,67)}$. However, subthalamotomy with FUS is being examined ${ }^{39)}$. A pilot study of unilateral subthalamotomy using MRgFUS in 10 patients has recently reported that motor UPDRS scores improved by 53\% in the off-medication state and by $47 \%$ in the on-medication state at 6 months after surgery $^{77)}$. Over 6 months follow-up, a total of 38 adverse events were recorded, including three persisting events that were directly STN-related, namely, off-medication choreic dyskinesia, on-medication non-disabling dyskinesia, and subjective speech disturbance. The two aforementioned patients suffering from involuntary movements after subthalamotomy had resolution of symptoms by 6 months postoperatively after adjusting medication. Currently, other phase I subthalamotomy studies are also underway (NCT02246374, NCT03454425) (Table 2).

\section{Psychiatric disease}

The feasibility of MRgFUS in obsessive-compulsive disorder (OCD) and major depressive disorder (MDD) is being investigated. A common surgical target in treatment-resistant patients include the anterior limb of the internal capsule (ALIC) $^{41,82)}$. ALIC fiber tracts carry information between the limbic cortices and thalamus and are thought to be associated with mood and anxiety disorders ${ }^{25,60,103)}$. The first reported clinical trial for MRgFUS bilateral capsulotomy was completed in in four medically refractory OCD patients ${ }^{58)}$. The Yale-
Brown Obsessive-Compulsive Scale (Y-BOCS) score gradually improved by $33 \%$ over 6-month follow-up period, while Hamilton Rating Scale for Depression (HAM-D) and Hamilton Rating Scale for Anxiety (HAM-A) scores were immediately relieved by $61.1 \%$ and $69.4 \%$, respectively, after surgery in all patients and such effects were sustained during the same period. A recent study by the same group in 11 OCD patients has shown that the above-mentioned clinical effects were maintained for 2 years, with Y-BOCS, HAM-D, and HAM-A scores being improved by $38 \%, 60 \%$, and $65 \%$, respectively ${ }^{63}$. Meanwhile, the first MRgFUS lesioning for MDD was also performed with the ALIC as the target, reporting significant improvements of HAM-D and Beck Depression Inventory scores by $73 \%$ and $54 \%$, respectively, at 12 months after surgery $^{62}$. Clinical trials (NCT02348411, NCT03421574) are underway to further evaluate the safety and initial effectiveness of MRgFUS bilateral capsulotomy for medically refractory MDD patients.

\section{Chronic neuropathic pain}

In chronic neuropathic pain, RF ablative surgery of the central thalamus has been successfully performed in medicationrefractory patients, spurring the application of MRgFUS to this condition ${ }^{123,126)}$. One study that performed MRgFUS-mediated central lateral thalamotomy reported mean pain relief of 57\% at 12 months follow-up in eight patients ${ }^{54)}$. Clinical trials continue to investigate the effects of MRgFUS thalamotomy for chronic neuropathic pain (NCT03255395, NCT03309813) ${ }^{82}$.

\section{Epilepsy}

Pilot studies are underway for MRgFUS-mediated ablation for epilepsy : one study aims to ablate subcortical lesion using MRgFUS for secondary generalized epilepsy due to subcortical lesion (NCT02804230). Another study plans to target the anterior thalamic nucleus to prevent secondary generalization in focal onset epilepsy patients (NCT03417297).

\section{BRAIN TUMOR ABLATION}

Stereotactic radiosurgery and conventional radiation therapy have been performed as an alternative or adjunct to open surgery in brain tumor patients. Radiation is associated with a long-term risk of adverse effect such as leukoencephalopathy 
in the surrounding tissues of the target despite careful treatment planning to reduce radiation toxicity ${ }^{75)}$. Thermal ablative therapy has been studied as another alternative to open surgery. MR-guided laser interstitial thermal therapy (LITT) is a novel stereotactic technique that ablates target tissue using a laser probe while monitoring the extent of thermal ablation using MR thermometry in real time. It has been applied to some selected epilepsies and malignant brain tumors as an alternative treatment, with promising initial results ${ }^{9,59)}$. However, LITT still requires a skin incision and a small drill hole to insert the laser probe and can sometimes exacerbate mass effect by causing malignant peritumoral edema ${ }^{9}$. The first application of MRgFUS to brain tumor ablation was reported in 2010 in three patients with glioblastomas, however, at that time, the target temperature for achieving thermal coagulation $\left(>55^{\circ} \mathrm{C}\right)$ could not be reached due to lack of specification of MRgFUS equipment and thus did not induce coagulative necrosis in the target ${ }^{79)}$. With newer equipment in 2014, MRgFUS-mediated thermal ablation was tried in a patient with recurrent glioblastoma in the thalamic and subthalamic region with a volume of $6.5 \mathrm{~mL}^{27}$. Of the total 25 sonications applied by increasing the acoustic energy in a stepwise manner up to 19950 J per sonication, 17 sonications reached above $55^{\circ} \mathrm{C}$ with a maximum peak temperature of $65^{\circ} \mathrm{C}$. Preoperative contralateral hemiparesis improved from motor grade $3 / 5$ to $4 / 5$ after treatment without any adverse effect. Signal change in the sonicated tumor tissue was visible as bright zone in diffusion weighted images immediately after treatment. At 5 days postoperatively, non-enhancing areas were found in the sonicated tumor tissue on $\mathrm{T} 1$ weighted images with contrast, and this effect lasted over 21 days follow-up period. Clinical studies (NCT 00147056, NCT 01473485) are currently underway to verify the safety and efficacy of MRgFUS-mediated brain tumor ablation, with one study being pending to report (NCT01698437). MRgFUS tumor ablation has been limited to brain tumors deeper than $2.5 \mathrm{~cm}$ from the skull, because of the risk of significantly increasing the temperature of the scalp, skull and surrounding brain tissue when MRgHIFU ablation is applied to brain tumors near the skull. In the future, the feasibility of MRgFUS ablation in larger volume or high vascularity tumors should also be studied, as well as the role of MRgFUS ablation in tumor control as an independent or an adjuvant therapy for other treatment modalities.

\section{PRECLINICAL STUDIES OF HIFU APPLICATION WITH NON-THERMAL MECHANISM}

\section{Sonothrombolysis}

A preclinical study investigated the feasibility of MRgFUSmediated thrombolysis of intracerebral hemorrhage $(\mathrm{ICH})^{85}$. In a swine model of ICH, the authors demonstrated that implanted clots with a volume of $4 \mathrm{~mL}(\mathrm{n}=5)$ were completely lysed by MRgFUS (parameters : $230 \mathrm{kHz}$, pulse repetition rate $1 \mathrm{kHz}$, duty cycle 10\%, and sonication duration 30 seconds) that was performed after 3 hours of clot dwell time. Sonication at $750 \mathrm{~W}$ was applied in craniotomized pigs, whereas $1500 \mathrm{~W}$ was required in pigs with the skull intact. There was neither evidence of blood-brain barrier disruption nor necrosis caused by thermal injury in the adjacent normal brain. In cadaveric model of ICH, all clots with a mean ICH volume of $27 \mathrm{~mL}(\mathrm{n}=4)$ were liquefied over $95 \%$ of each clot after transcranial MRgFUS (parameters : $230 \mathrm{kHz}$, power of $3950 \mathrm{~W}$, sonication duration 30 seconds, $1 \mathrm{kHz}$ pulse repetition rate, and $10 \%$ duty cycle), except for one ICH in which ultrasound energy could not reach its target due to interaction of the dissolved gas generated by the decay of specimen. The researchers also studied the feasibility of MRgFUS thrombolysis for intraventricular hemorrhage using a cadaveric model $(n=1)$, reporting that significant volume of thrombus was lysed after a single sonication using the same parameters as described above.

\section{Cerebrospinal fluid diversion}

One study demonstrated the technical feasibility of noninvasive third ventriculostomy using MRgFUS in pigs. Inertial cavitation was generated, resulting in tissue fractionation, with higher peak rarefaction pressures than those used in thermal ablation ${ }^{4)}$. Seven pigs underwent sonication at 650 $\mathrm{kHz}$ via craniectomy, while two underwent sonication (one at $650 \mathrm{kHz}$ and another at $230 \mathrm{kHz}$ ) through an ex vivo human skull placed over the beam pathway after craniectomy was performed. Third ventriculostomy was successfully performed in 6 of 9 swine including one treated at $230 \mathrm{kHz}$ through the skull. A small amount of subarachnoid hemorrhage was observed around the successful ventriculostomies, and in the animal treated transcranially at $650 \mathrm{kHz}$, microhemorrhage was identified at a site distal from the target. Therefore, in future studies, optimization of ultrasonic parameters 
MRgFUS-Mediated Thermal Ablation and BBB Opening I Lee EJ, et al.

Table 3. Preclinical research on MRgFUS-facilitated targeted drug delivery

\begin{tabular}{|c|c|c|c|c|c|c|}
\hline $\begin{array}{l}\text { Disease } \\
\text { indication }\end{array}$ & Drug category & $\begin{array}{c}\text { Therapeutic agent of } \\
\text { interest }\end{array}$ & $\begin{array}{l}\text { Subject/disease } \\
\text { model }\end{array}$ & FUS parameters* & Results & Year \\
\hline \multirow[t]{14}{*}{ Brain tumor } & \multirow{6}{*}{$\begin{array}{l}\text { Conventional } \\
\text { chemotherapy }\end{array}$} & Lipo-Dox & Rat/gliosarcoma & $\begin{array}{l}1700 ; 1.2 ; 10 ; 1 ; 60-120,5-9 \\
\text { sonications in total }\end{array}$ & $\begin{array}{l}\downarrow \text { tumor growth } \\
\uparrow \text { survival }\end{array}$ & $2012^{116)}$ \\
\hline & & IL-4 targeted Lipo-Dox & Mouse/GBM & $1000 ; 0.7 ; ; 1:{ }_{-,} 5 \%$ duty cycle & $\begin{array}{l}\downarrow \text { tumor growth } \\
\uparrow \text { survival }\end{array}$ & $2012^{124)}$ \\
\hline & & Lipo-Dox & Rat/gliosarcoma & $\begin{array}{l}690 ; 0.55-0.81 ; 10 ; 1 ; 60,5-20 \\
\text { sonications in total, } 3 \text { weekly } \\
\text { treatments }\end{array}$ & $\begin{array}{l}\downarrow \text { tumor growth, } \\
\uparrow \text { survival }\end{array}$ & $2013^{8)}$ \\
\hline & & Free Dox & Mouse/GBM & $612.5 ; 0.4 ; 10 ; 1 ; 180$ & $\begin{array}{l}\downarrow \text { tumor growth } \\
\uparrow \text { survival }\end{array}$ & $2014^{66)}$ \\
\hline & & BCNU & Rat/GBM & $400 ; 0.62 ; 10 ; 1 ; 30$ & $\begin{array}{l}\downarrow \text { tumor growth } \\
\uparrow \text { survival }\end{array}$ & $2010^{73)}$ \\
\hline & & $\mathrm{TMZ}$ & Rat/gliosarcoma & $500 ; 0.6 ; 10 ; 1 ; 60$ & $\begin{array}{l}\downarrow \text { tumor growth } \\
\uparrow \text { survival }\end{array}$ & $2013^{122)}$ \\
\hline & \multirow[t]{2}{*}{$\begin{array}{l}\text { Monoclonal } \\
\text { antibody }\end{array}$} & Anti-HER2 Ab (Herceptin) & Mouse/normal & $690 ; 0.6$ or $0.8 ; 10 ; 1 ; 40$ & Targeted Ab delivery & $2006^{64)}$ \\
\hline & & Anti-HER2 Ab (Herceptin) & $\begin{array}{l}\text { Rat/metastatic breast } \\
\text { cancer (HER2+) }\end{array}$ & $\begin{array}{c}690 ; 0.69 ; 10 ; 1 ; 60,6 \text { weekly } \\
\text { treatments }\end{array}$ & $\begin{array}{l}\downarrow \text { tumor size } \\
\uparrow \text { survival }\end{array}$ & $2012^{95)}$ \\
\hline & \multirow[t]{3}{*}{ Nanoparticle } & $\begin{array}{l}\text { Epirubicin immobilized on } \\
\text { MNP }\end{array}$ & Rat/GBM & $400 ; 0.62 ; 1 ; 10 ; 1 ; 120$ & $\begin{array}{l}\downarrow \text { tumor growth } \\
\uparrow \text { survival }\end{array}$ & $2010^{74)}$ \\
\hline & & $\begin{array}{l}\text { BCNU immobilized on } \\
\text { MNP }\end{array}$ & Rat/GBM & $400 ; 0.7 ; 10 ; 1 ; 30$ & $\downarrow$ tumor growth & $2010^{23)}$ \\
\hline & & $\begin{array}{l}\text { Cisplatin immobilized on } \\
\text { NP }\end{array}$ & $\begin{array}{l}\text { Rat/gliosarcoma, } \\
\text { GBM }\end{array}$ & $\begin{array}{c}1140 ; 0.6 \text { or } 0.8 ; \_;-; 120,0.5 \% \\
\text { duty cycle }\end{array}$ & $\begin{array}{l}\downarrow \text { tumor growth } \\
\uparrow \text { survival }\end{array}$ & $2017^{114)}$ \\
\hline & Gene therapy & $\begin{array}{l}\text { HSV1-tk-loaded VCMBs/ } \\
\text { ganciclovir }\end{array}$ & Rat/GBM & $1000 ; 0.7 ;-; 5 ; 120$ & $\begin{array}{l}\downarrow \text { tumor growth } \\
\uparrow \text { survival }\end{array}$ & $2017^{18)}$ \\
\hline & \multirow[t]{2}{*}{ Cells } & $\begin{array}{l}\text { NK-92 cells (chimeric HER2 } \\
\text { antigen receptor+) }\end{array}$ & $\begin{array}{l}\text { Rat/metastatic breast } \\
\text { cancer (HER2+) }\end{array}$ & $551.5 ; 0.33 ; 10 ; 1 ; 120$ & $\begin{array}{l}\uparrow \text { NK-92 cell } \\
\text { accumulation at the } \\
\text { tumor sites }\end{array}$ & $2013^{2)}$ \\
\hline & & $\begin{array}{l}\text { NK-92 cells (chimeric HER2 } \\
\text { antigen receptor+) }\end{array}$ & $\begin{array}{l}\text { Rat/metastatic breast } \\
\text { cancer (HER2+) }\end{array}$ & 551.5;_; 10; $2 ; 120$ & $\begin{array}{l}\downarrow \text { tumor growth and } \\
\uparrow \text { survival in the } \\
\text { front-loaded } \\
\text { treatment }\end{array}$ & $2016^{3)}$ \\
\hline \multirow[t]{3}{*}{$A D$} & Antibody & Anti-Aß Ab & Tg mouse/AD & $690 ; 0.67-0.8 ; 10 ; 1 ; 40-45$ & $\begin{array}{l}\uparrow \text { Ab delivery } \\
\uparrow \text { endogenous IgG }\end{array}$ & $2008^{98)}$ \\
\hline & & Anti-AB Ab (BAM-10) & Tg mouse/AD & $558 ; 0.3 ; 10 ; 1 ; 120$ & $\downarrow$ A $\beta$ plaques & $2010^{56)}$ \\
\hline & Nanoparticle & $\begin{array}{l}\text { Anti-Aß Ab (6E10) } \\
\text { immobilized on NP }\end{array}$ & Tg mouse/AD & 2500; 0.95-2.21;_;_;60 & $\uparrow A b$ delivery & $2014^{125)}$ \\
\hline \multirow{2}{*}{ Parkinson's disease } & Antibody & Anti-DRD4 Ab & Mouse/normal & $690 ; 0.6-1.1 ; 10 ; 1 ; 40$ & $\uparrow$ Ab delivery & $2006^{65)}$ \\
\hline & Drug & Lipo-rhFGF20 & $\begin{array}{l}\text { Rat/6-OHDA } \\
\text { lesioned }\end{array}$ & 690;_; $10 ; 1 ; 60,3 \mathrm{~W}$ & $\begin{array}{l}\uparrow \text { drug delivery } \\
\downarrow \text { motor dysfunction } \\
\downarrow \text { DA neuronal loss }\end{array}$ & $2018^{90)}$ \\
\hline $\begin{array}{l}\text { Huntington's } \\
\text { disease }\end{array}$ & Gene therapy & cc-siRNA-Htt & Rat/normal & $558 ; 0.3 ; 10 ; 1 ; 120$ & $\downarrow$ Htt expression & $2012^{13)}$ \\
\hline \multirow[t]{2}{*}{ Unspecified } & \multirow[t]{2}{*}{ Gene therapy } & AAV9-GFP & Mouse/normal & $1180 ; 0.53-0.6 ; 10 ; 1 ; 120$ & \multirow{2}{*}{$\begin{array}{l}\text { Targeted GFP expression } \\
\text { Targeted GFP expression }\end{array}$} & $2012^{113)}$ \\
\hline & & AAV2-GFP & Mouse/normal & $1500 ; 0.44-0.7 ; 10 ; 1 ; 120$ & & $2013^{46)}$ \\
\hline
\end{tabular}

*Frequency (kHz); negative peak pressure (MPa); burst length (ms); repetition frequency (Hz); total US duration (sec). MRgHIFU : magnetic resonanceguided focused ultrasound, FUS : focused ultrasound, Lipo-Dox : liposomal doxorubicin, $\downarrow$ : inhibition/reduction, $\uparrow$ : increase, GBM : glioblastoma multiforme, _ : unspecified, BCNU : 1,3-Bis(2-chloroethyl)-1-nitrosourea, TMZ : temozolomide, HER2 : human epidermal growth factor receptor 2, Ab : antibody, MNP : magnetic nanoparticle, NP : nanoparticle, HSV1-tk : herpes simplex virus type 1-thymidine kinase, VCMB : VEGFR2-targeted and cationic microbubble, NK : natural killer, AB : amyloid-beta, AD : Alzheimer's disease, IgG : immunoglobulin G, DRD4 : dopamine receptor D4, rhFGF20 : recombinant human fibroblast growth factor-20, OHDA : hydroxydopamine, Tg : transgenic, DA : dopaminergic, cc-siRNA : cholesterol-conjugated small interfering RNA, Htt : Huntingtin protein, AAV : adeno-associated virus, GFP : green fluorescent protein 
to improve the safety and efficacy of this procedure is of paramount importance.

\section{CLINICAL APPLICATION OF PULSED FUS FOR BBB OPENING}

The $\mathrm{BBB}$ is a major impediment to effective pharmaceutical treatment of a wide array of intracranial diseases ${ }^{14,36)}$. Cerebral endothelial cells, which constitute the BBB, have several unique anatomical features which endow them with formidable barrier properties, that is, the presence of tight junctions between neighboring cells and remarkably fewer transport vesicles and fenestrations compared to other tissues. These attributes impede the paracellular and transcellular transports of molecules, respectively ${ }^{14,30)}$. Moreover, the BBB expresses drug-efflux transporters such as P-glycoproteins that pump foreign substances out of the cells ${ }^{7,36)}$. For these reasons, most systemically administered therapeutic agents, except nonpolar lipophilic small agents ( $<400 \mathrm{Da})$ that readily pass the BBB, are unable to cross the BBB to the levels sufficient to achieve therapeutic quantities ${ }^{93,94)}$. Several attempts have been made to overcome this problem such as reducing the size or increasing the lipid solubility of therapeutic agents, transiently osmotically opening the BBB, or to administer agents intranasally in order to bypass the BBB. As part of this effort, MRgFUS has been explored for its BBB-opening effects ${ }^{14)}$. Several preclinical studies have demonstrated that pulsed ultrasound can safely open the BBB with spatial and temporal specificity at selected ultrasound parameters, resulting in significant increase in drug concentration at the target site ${ }^{50,511}$. The extent of BBB opening depends on the size and concentration of intravenously delivered preformed microbubbles, as well as ultrasound parameters such as intensity and sonication time ${ }^{14}$. Simultaneously, precise targeting of BBB disruption can be estimated by regional contrast extravasation on the MR images which correlates with the amount of drug delivery ${ }^{22,15)}$. FUSmediated BBB opening is transient but lasts for approximately 4-6 hours after treatment, before the BBB closes again ${ }^{78,80,104)}$.

\section{Brain tumors}

Over the past decade, many preclinical studies on FUS-mediated BBB opening to enhance drug delivery and to improve the treatment efficacy for various intracranial diseases have

Table 4. Current status of clinical trials on pulsed LIFU application for BBB opening

\begin{tabular}{|c|c|c|c|c|c|c|c|}
\hline Indication & Stage & Subtype & $\begin{array}{l}\text { US treated } \\
\text { region }\end{array}$ & Drug & End points & US Device/US parameters & Status \\
\hline \multirow[t]{3}{*}{ Brain tumor } & Phase I/IIa & $\begin{array}{l}\text { Recurrent } \\
\text { GBM }\end{array}$ & Tumor & Carboplatin & $\begin{array}{l}\text { Safety, feasibility of } \\
\text { BBBD, PFS, OS }\end{array}$ & $\begin{array}{l}\text { SonoCloud }{ }^{\circledast} \text { (CarThera, Paris, } \\
\text { France) } 0.5-1.1 \mathrm{MPa}\end{array}$ & $\begin{array}{l}\text { Recruiting } \\
\text { (NCT02253212) }\end{array}$ \\
\hline & Phase I & GBM & $\begin{array}{l}\text { Resected surgical } \\
\text { cavity }\end{array}$ & I TMZ & $\begin{array}{l}\text { Safety, feasibility of } \\
\text { repeated BBBD }\end{array}$ & $\begin{array}{l}\text { f ExAblate }{ }^{\circledast} \text { (InSightec, Tirat } \\
\text { Carmel, Israel) } 220 \text { kHz }\end{array}$ & $\begin{array}{l}\text { Not yet recruiting } \\
\text { (NCT03551249, } \\
\text { NCT03616860) }\end{array}$ \\
\hline & Phase I & Unspecified & Tumor & Doxorubicin & $\begin{array}{l}\text { Safety, feasibility } \\
\text { of BBBD }\end{array}$ & ExAblate $^{\circledast}$ (InSightec) 220 kHz & $\begin{array}{l}\text { Recruiting } \\
\text { (NCT02343991) }\end{array}$ \\
\hline \multirow[t]{4}{*}{$\begin{array}{l}\text { Neurodegenerative } \\
\text { disease }\end{array}$} & Phase I & $\begin{array}{l}\text { Mild to } \\
\text { moderate } \\
\text { PDD }\end{array}$ & $\begin{array}{l}\text { Right parieto- } \\
\text { occipito- } \\
\text { temporal lobes }\end{array}$ & No & $\begin{array}{l}\text { Safety, feasibility } \\
\text { of BBBD }\end{array}$ & ExAblate $^{\circledast}$ (InSightec) 220 kHz & $\begin{array}{l}\text { Recruiting } \\
\text { (NCT03608553) }\end{array}$ \\
\hline & Phase I & Mild AD & Frontal lobes & No & $\begin{array}{l}\text { Safety, feasibility } \\
\text { of } B B B D, \triangle A \beta \\
\text { plaques }\end{array}$ & $\begin{array}{l}\text { ExAblate }^{\oplus} \text { (InSightec) } 220 \mathrm{kHz} \\
4.6 \text { W for stage } 14.5 \mathrm{~W} \text { for } \\
\text { stage } 2\end{array}$ & $\begin{array}{l}\text { Completed and } \\
\text { published }^{71)} \\
\text { (NCT02986932) }^{\text {NCT }}\end{array}$ \\
\hline & Phase I/II & Mild AD & $\begin{array}{l}\text { Left } \\
\text { supramarginal } \\
\text { gyrus }\end{array}$ & No & $\begin{array}{l}\triangle \text { glucose } \\
\text { metabolism, } \\
\text { safety of BBBD }\end{array}$ & $\begin{array}{l}\text { SonoCloud }{ }^{\circledR} \text { (CarThera) } \\
\text { unspecified }\end{array}$ & $\begin{array}{l}\text { Recruiting } \\
\text { (NCT03119961) }\end{array}$ \\
\hline & Phase I & ALS & $\begin{array}{l}\text { Primary motor } \\
\text { cortex }\end{array}$ & No & $\begin{array}{l}\text { Safety, feasibility } \\
\text { of BBBD }\end{array}$ & $\begin{array}{l}\text { ExAblate }^{\oplus} \text { (InSightec) } \\
\text { unspecified }\end{array}$ & $\begin{array}{l}\text { Recruiting } \\
\text { (NCT03321487) }\end{array}$ \\
\hline
\end{tabular}

LIFU : low-intensity focused ultrasound, BBB : blood-brain barrier, US : ultrasound, GBM : glioblastoma multiforme, BBBD : blood-brain barrier disruption, PFS : progression-free survival, OS : overall survival, TMZ : temozolomide, PDD : Parkinson's disease with dementia, AD : Alzheimer's disease, $\triangle$ : change in, $A \beta$ : amyloid- $\beta$, ALS : amyotrophic lateral sclerosis 
been conducted. Several animal studies have taken place including : targeted therapies of malignant gliomas and metastatic brain tumors using various types of therapeutic agents including monoclonal antibodies (e.g., trastuzumab for HER 2-positive breast cancer brain metastasis), gene therapy agents, and immune cells as well as conventional chemotherapeutic agents including doxorubicin and temozolomide. These studies consistently showed enhanced drug delivery into tumors, which led to inhibition of tumor growth as well as improved survival (Table 3). Though ultrasound parameters varied in the literature, the acoustic negative peak pressure generally ranged between $0.3-1.0 \mathrm{MPa}$, and as pressure increased beyond 0.8 $\mathrm{MPa}$, erythrocyte extravasation was observed more frequent$1 \mathrm{y}^{18,64)}$. These promising preclinical results have promoted translation to clinical application of FUS-mediated BBB opening and enhanced drug delivery to the brain, with several phase I or I/IIa clinical trials for malignant brain tumors underway (NCT02253212, NCT03551249, NCT03616860, NCT02343991) (Table 4). Carpentier et al. ${ }^{17)}$ have recently reported the interim results of a clinical trial on the safety of ultrasound dose-escalation ranging from 0.5 to $1.1 \mathrm{MPa}$ using SonoCloud ${ }^{\circledR}\left(\right.$ Car- $^{-}$ Thera, Paris, France), an implantable pulsed ultrasound system in the recurrent glioblastoma patients. The authors demonstrated that repeated monthly BBB opening was safe up to 1.1 $\mathrm{MPa}$, with the extent of $\mathrm{BBB}$ opening being most effective with acoustic pressures of $\geq 0.8 \mathrm{MPa}$ (NCT02253212).

\section{Neurodegenerative diseases}

FUS is being examined for its potential role in neurodegenerative diseases including Alzheimer's disease (AD), PD, and Huntington's disease (HD). In 2008, Raymond et al. ${ }^{98)}$ reported that using a transgenic mouse model of AD, FUS-mediated BBB opening increased anti-amyloid beta $(\mathrm{A} \beta)$ antibodies bound to $A \beta$ plaques 2.7-fold in targeted areas. Another study using a transgenic mouse model of $\mathrm{AD}$ also demonstrated enhanced delivery of anti-A $\beta$ monoclonal antibody (BAM-10) following MRgFUS application and significant reduction in $\mathrm{A} \beta$ plaques number and size (both $12 \%$ ) as well as the surface area covered by $\mathrm{A} \beta$ plaques (23\%) in the FUS-treated areas ${ }^{56)}$. These results were seen in 4 days with only one treatment. Surprisingly, FUS-mediated BBB opening alone has also proven to induce significant $A \beta$ plaque reduction ${ }^{12,57,69)}$. Studies showed that endogenous immunoglobulins (IgG and $\operatorname{IgM}$ ), which were present in the blood circulation, entered the brain after FUS-mediated BBB opening and bound to $A \beta$ plaques, leading to activation of the innate immune system against pathologic proteins. Through such mechanism, FUS seems to assist in clearing $A \beta$ plaques even without externally-administered antibodies. Also, activation of astrocytes and microglia was found, as well as increased internalization of $A \beta$ within these cells following FUS treatment ${ }^{57}$. After a single treatment with FUS alone, $A \beta$ plaque size and total surface area decreased significantly by $20 \%$ and $13 \%$, respectively, and $A \beta$ plaque number trended to decrease by $9 \%$, which were comparable to the results of previous studies of FUS treatment with antibodies ${ }^{56,57)}$. In addition, and even more surprisingly, sonication was reported to increase neurogenesis in the hippocampus ${ }^{12,101)}$. Scarcelli et al. ${ }^{101)}$ demonstrated that pulsed LIFU combined with microbubbles applied at typical parameters for BBB opening $(10 \mathrm{~ms}$ bursts, $1 \mathrm{~Hz}$ pulse repetition frequency, mean peak pressures of $0.96 \mathrm{MPa}$, and duration of 120 seconds) is able to stimulate neurogenesis (228\% increase) in the dentate gyrus of the hippocampus of adult mice. Another study by the same group also verified the ability of inducing neurogenesis of pulsed LIFU. The authors applied MRgFUS (10 ms bursts, $1 \mathrm{~Hz}$ pulse repetition frequency, mean peak pressure of $1.18 \mathrm{MPa}$, and duration of 120 seconds) targeting the dorsal hippocampus with microbubbles using transgenic mouse model of $\mathrm{AD}$ and demonstrated that the number of newborn neurons in the dentate gyrus of the hippocampus significantly increased by $252 \%$ after 4 weekly ultrasound treatment ${ }^{12}$. Also, total dendrite length (323\%) and branching were significantly greater in the ultrasound treated animals compared with untreated controls. Along with significant decrease in the $A \beta$ plaque burden (size, number, and the surface area loaded by $A \beta$ by $20 \%, 29 \%$, and $19 \%$, respectively) in the hippocampus after MRgFUS treatment, the neuronal proliferation and maturation in the dentate gyrus was correlated with spatial memory improvement. The mechanism by which FUS mediates the hippocampal neurogenesis at the BBB opening parameter has not yet been established. One potential mechanism may be illustrated with mechanical bioeffect of pulsed LIFU on stimulation of neurons, which is accompanied by activation of cellular molecular signaling cascade and in turn upregulation of trophic cytokine such as brain-derived neurotrophic factor (BDNF) and vascular endothelial growth factor which are essential for promoting hippocampal neurogenesis $^{12,16,99,101,117)}$. Tufail et al. ${ }^{117)}$ reported that pulsed LIFU 
(0.35 MHz, 50 cycles per pulse, $1.5 \mathrm{kHz}$ pulse repetition frequencies, 500 pulses) without microbubble contrast agents targeted on the hippocampus of mouse significantly increased the density of BDNF in CA1 (148\%) and CA3 regions (158\%) of the hippocampus. Although the ultrasound parameters to elicit neuromodulatory effects are typically different from those for BBB opening, these observations suggest that pulsed LIFU may promote neurogenesis through a similar mechanism, even at BBB opening parameters, though further confirmatory studies are needed. Another potential mechanism might be explained as activation of PI3K-Akt-mTOR signaling pathway, which promotes cellular survival and growth, in response to FUS-mediated BBB opening ${ }^{12}$. Indeed, activation of PI3K-Akt-mTOR signaling leads to improve survival of newborn neurons in the dentate gyrus in the adult mouse model of $\mathrm{AD}$, rescuing newborn neurons from $\mathrm{A} \beta$-induced dendritic growth deficits ${ }^{70)}$. Jalali et al. ${ }^{53)}$ demonstrated that ultrasoundmediated BBB opening combined with microbubbles in rats induced activation of PI3K-Akt signaling pathway in the neurons. Taken together, these findings suggest that FUS-mediated BBB opening has interesting potential as a therapeutic strategy for AD treatment. Recently, the results of a phase I safety and feasibility trial for FUS-mediated BBB opening in mild AD patients have been published (NCT02986932) ${ }^{72}$. In conjunction with intravenous microbubble contrast, MRgFUS was applied to a small volume of white matter in the frontal lobe in five patients. In all patients, BBB opening was successful without serious adverse events, but without any evidence of amyloid clearance as measured by positron emission tomography. Another phase I/II trial of BBB opening in mild AD patients is being underway (NCT03119961) (Table 4). For other neurodegenerative diseases such as PD and HD, preclinical and clinical trials are underway (Tables 3 and 4). Burgess et al. studied the feasibility of MRgFUS-facilitated non-invasive gene therapy to silence the mutant Huntingtin (Htt) gene that results in expression of abnormal Htt protein causing progressive neuronal damage in $\mathrm{HD}^{13}$. Decrease in Htt protein expression had proven to correlate with improved motor function and neuronal survival in the mouse model of HD, however, cholesterol-conjugated small interfering RNA against Htt (cc-siRNA-Htt), which reverses pathology, was injected into the striatum in an invasive manner in the previous study ${ }^{31}$. Instead, Burgess et al. ${ }^{13)}$ used MRgFUS to enhance the delivery of intravenously administered cc-siRNA-Htt into the striatum and demonstrat- ed significant Htt knockdown. These results suggest that MRgFUS-mediated gene therapy could be a promising therapeutic approach for genetic neurological disorders.

\section{SUMMARY}

MRgFUS is an emerging technique allowing non-invasive, incision-free transcranial treatment for a variety of intracranial diseases via thermal and non-thermal mechanisms. Accurate thermal ablation via MRgHIFU-mediated stereotactic lesioning can be confirmed with real-time visualization of the target volume with MRI thermometry. In ET and PD patients, MRgHIFU is being performed unilaterally due to concern over the high incidence of adverse effects associated with bilateral lesions ${ }^{5}$, and clinical studies are ongoing to assess its long-term safety and efficacy. In addition, emerging preclinical evidence suggests that MRgFUS-mediated BBB opening has potential to revolutionize the targeted treatment of selected brain diseases, including brain tumors and neurogenerative disease. Lots of work is needed to establish safe and effective ultrasound parameters before routinely applying MRgFUSmediated BBB opening to humans. As such, several phase 1 clinical trials are being conducted by research institutes worldwide. We are now seeing the advent of a new era in the treatment of brain diseases.

\section{CONFLICTS OF INTEREST}

No potential conflict of interest relevant to this article was reported.

\section{INFORMED CONSENT}

This type of study does not require informed consent.

\section{References}

1. Adrianov OS, Vykhodtseva NI, Fokin VF, Uranova NA, Avirom VM : Reversible functional shutdown of the optic tract on exposure to focused ultrasound. Biull Eksp Biol Med 97 : 760-762, 1984 
2. Alkins $R$, Burgess $A$, Ganguly M, Francia G, Kerbel R, Wels WS, et al. : Focused ultrasound delivers targeted immune cells to metastatic brain tumors. Cancer Res 73 : 1892-1899, 2013

3. Alkins $R$, Burgess $A$, Kerbel R, Wels WS, Hynynen $K$ : Early treatment of HER2-amplified brain tumors with targeted NK-92 cells and focused ultrasound improves survival. Neuro Oncol 18 : 974-981, 2016

4. Alkins $R$, Huang $Y$, Pajek $D$, Hynynen $K$ : Cavitation-based third ventriculostomy using MRI-guided focused ultrasound. J Neurosurg 119 : 1520-1529, 2013

5. Alomar S, King NK, Tam J, Bari AA, Hamani C, Lozano AM : Speech and language adverse effects after thalamotomy and deep brain stimulation in patients with movement disorders: a meta-analysis. Mov Disord 32 : 53-63, 2017

6. Alvarez L, Macias R, Pavón N, López G, Rodríguez-Oroz MC, Rodríguez R, et al. : Therapeutic efficacy of unilateral subthalamotomy in Parkinson's disease: results in 89 patients followed for up to 36 months. J Neurol Neurosurg Psychiatry 80 : 979-985, 2009

7. Alvarez M, Paull K, Monks A, Hose C, Lee JS, Weinstein J, et al. : Generation of a drug resistance profile by quantitation of $\mathrm{mdr}-1 / \mathrm{P}$-glycoprotein in the cell lines of the National Cancer Institute Anticancer Drug Screen. J Clin Invest 95 : 2205-2214, 1995

8. Aryal M, Vykhodtseva N, Zhang YZ, Park J, McDannold N : Multiple treatments with liposomal doxorubicin and ultrasound-induced disruption of blood-tumor and blood-brain barriers improve outcomes in a rat glioma model. J Control Release 169 : 103-111, 2013

9. Beaumont TL, Mohammadi AM, Kim AH, Barnett GH, Leuthardt EC : Magnetic resonance imaging-guided laser interstitial thermal therapy for glioblastoma of the corpus callosum. Neurosurgery 83 : 556-565, 2018

10. Bond AE, Shah BB, Huss DS, Dallapiazza RF, Warren A, Harrison MB, et al. : Safety and efficacy of focused ultrasound thalamotomy for patients with medication-refractory, tremor-dominant parkinson disease: a randomized clinical trial. JAMA Neurol 74 : 1412-1418, 2017

11. Borrelli MJ, Bailey KI, Dunn F : Early ultrasonic effects upon mammalian CNS structures (chemical synapses). J Acoust Soc Am 69 : 1514-1516, 1981

12. Burgess A, Dubey S, Yeung S, Hough O, Eterman N, Aubert I, et al. : Alzheimer disease in a mouse model: MR imaging-guided focused ultrasound targeted to the hippocampus opens the blood-brain barrier and improves pathologic abnormalities and behavior. Radiology 273 : 736745, 2014

13. Burgess A, Huang Y, Querbes W, Sah DW, Hynynen K : Focused ultrasound for targeted delivery of siRNA and efficient knockdown of $\mathrm{Htt}$ expression. J Control Release 163 : 125-129, 2012

14. Burgess A, Shah K, Hough O, Hynynen K : Focused ultrasound-mediated drug delivery through the blood-brain barrier. Expert Rev Neurother 15 : 477-491, 2015

15. Bystritsky A, Korb AS, Douglas PK, Cohen MS, Melega WP, Mulgaonkar $A P$, et al. : A review of low-intensity focused ultrasound pulsation. Brain Stimul 4: 125-136, 2011

16. Cao L, Jiao $X$, Zuzga DS, Liu Y, Fong DM, Young D, et al. : VEGF links hippocampal activity with neurogenesis, learning and memory. Nat Genet 36 : 827-835, 2004

17. Carpentier A, Canney M, Vignot A, Reina V, Beccaria K, Horodyckid $C$, et al. : Clinical trial of blood-brain barrier disruption by pulsed ultrasound. Sci Transl Med 8 : 343re342, 2016

18. Chang EL, Ting CY, Hsu PH, Lin YC, Liao EC, Huang CY, et al. : Angiogenesis-targeting microbubbles combined with ultrasound-mediated gene therapy in brain tumors. J Control Release 255 : 164-175, 2017

19. Chang JW, Park CK, Lipsman N, Schwartz ML, Ghanouni P, Henderson $J M$, et al. : A prospective trial of magnetic resonance-guided focused ultrasound thalamotomy for essential tremor: results at the 2-year followup. Ann Neurol 83 : 107-114, 2018

20. Chang WS, Jung HH, Kweon EJ, Zadicario E, Rachmilevitch I, Chang JW : Unilateral magnetic resonance guided focused ultrasound thalamotomy for essential tremor: practices and clinicoradiological outcomes. J Neurol Neurosurg Psychiatry 86 : 257-264, 2015

21. Chang WS, Jung HH, Zadicario E, Rachmilevitch I, Tlusty T, Vitek S, et al. : Factors associated with successful magnetic resonance-guided focused ultrasound treatment: efficiency of acoustic energy delivery through the skull. J Neurosurg 124 : 411-416, 2016

22. Chen $\mathrm{H}$, Konofagou EE : The size of blood-brain barrier opening induced by focused ultrasound is dictated by the acoustic pressure. J Cereb Blood Flow Metab 34 : 1197-1204, 2014

23. Chen PY, Liu HL, Hua MY, Yang HW, Huang CY, Chu PC, et al. : Novel magnetic/ultrasound focusing system enhances nanoparticle drug delivery for glioma treatment. Neuro Oncol 12 : 1050-1060, 2010

24. Chen PY, Wei KC, Liu HL : Neural immune modulation and immunotherapy assisted by focused ultrasound induced blood-brain barrier opening. Hum Vaccin Immunother 11 : 2682-2687, 2015

25. Christmas D, Eljamel MS, Butler S, Hazari H, MacVicar R, Steele JD, et al. : Long term outcome of thermal anterior capsulotomy for chronic, treatment refractory depression. J Neurol Neurosurg Psychiatry 82 : 594-600, 2011

26. Clement GT, White PJ, King RL, McDannold N, Hynynen K : A magnetic resonance imaging-compatible, large-scale array for trans-skull ultrasound surgery and therapy. J Ultrasound Med 24 : 1117-1125, 2005

27. Coluccia D, Fandino J, Schwyzer L, O'Gorman R, Remonda L, Anon J, et al. : First noninvasive thermal ablation of a brain tumor with MR-guided focused ultrasound. J Ther Ultrasound 2 : 17, 2014

28. Dalecki $D$ : Mechanical bioeffects of ultrasound. Annu Rev Biomed Eng 6 : 229-248, 2004

29. Dallapiazza RF, Timbie K, Elias WJ : Innovative Neuromodulation: Ultrasound Neuromodulation, ed 1. Cambridge : Academic Press, 2017, pp102-121

30. Davson H : Review lecture. The blood-brain barrier. J Physiol 255 : 1-28, 1976

31. Difiglia M, Sena-Esteves M, Chase K, Sapp E, Pfister E, Sass M, et al. : Therapeutic silencing of mutant huntingtin with siRNA attenuates striatal and cortical neuropathology and behavioral deficits. Proc Natl Acad Sci U S A 104 : 17204-17209, 2007

32. Dinno MA, Dyson M, Young SR, Mortimer AJ, Hart J, Crum LA : The 
significance of membrane changes in the safe and effective use of therapeutic and diagnostic ultrasound. Phys Med Biol 34 : 1543-1552, 1989

33. Duck FA : Medical and non-medical protection standards for ultrasound and infrasound. Prog Biophys Mol Biol 93 : 176-191, 2007

34. Elias WJ, Huss D, Voss T, Loomba J, Khaled M, Zadicario E, et al. : A pilot study of focused ultrasound thalamotomy for essential tremor. $\mathbf{N}$ Engl J Med 369 : 640-648, 2013

35. Elias WJ, Lipsman N, Ondo WG, Ghanouni P, Kim YG, Lee W, et al. : A randomized trial of focused ultrasound thalamotomy for essential tremor. N Engl J Med 375 : 730-739, 2016

36. Etame AB, Diaz RJ, Smith CA, Mainprize TG, Hynynen K, Rutka JT : Focused ultrasound disruption of the blood-brain barrier: a new frontier for therapeutic delivery in molecular neurooncology. Neurosurg Focus 32 : E3, 2012

37. Fasano A, Llinas M, Munhoz RP, Hlasny E, Kucharczyk W, Lozano AM : MRI-guided focused ultrasound thalamotomy in non-ET tremor syndromes. Neurology 89 : 771-775, 2017

38. Fenoy AJ, Simpson RK Jr : Risks of common complications in deep brain stimulation surgery: management and avoidance. J Neurosurg 120 : 132-139, 2014

39. Fishman PS, Frenkel V : Focused ultrasound: an emerging therapeutic modality for neurologic disease. Neurotherapeutics 14 : 393-404, 2017

40. Fomenko A, Neudorfer C, Dallapiazza RF, Kalia SK, Lozano AM : Lowintensity ultrasound neuromodulation: an overview of mechanisms and emerging human applications. Brain Stimul 11 : 1209-1217, 2018

41. Franklin ME, Foa EB : Treatment of obsessive compulsive disorder. Annu Rev Clin Psychol 7 : 229-243, 2011

42. Fry W : Neurosonic surgery. Trans Am Neurol Assoc (80th Meeting) : 86-88, 1955

43. Fry WJ : Intense ultrasound; a new tool for neurological research. J Ment Sci $100: 85-96,1954$

44. Fry WJ, Mosberg WH Jr, Barnard JW, Fry FJ : Production of focal destructive lesions in the central nervous system with ultrasound. J Neurosurg $11: 471-478,1954$

45. Fry WJ, Barnard JW, Fry FJ, Brennan JF : Ultrasonically produced localized selective lesions in the central nervous system. Am J Phys Med $34:$ 413-423, 1955

46. Hsu PH, Wei KC, Huang CY, Wen CJ, Yen TC, Liu CL, et al. : Noninvasive and targeted gene delivery into the brain using microbubble-facilitated focused ultrasound. PLoS One 8 : e57682, 2013

47. Huisman M, van den Bosch MA : MR-guided high-intensity focused ultrasound for noninvasive cancer treatment. Cancer Imaging 11 : S161S166, 2011

48. Huss DS, Dallapiazza RF, Shah BB, Harrison MB, Diamond J, Elias WJ : Functional assessment and quality of life in essential tremor with bilateral or unilateral DBS and focused ultrasound thalamotomy. Mov Disord 30 : 1937-1943, 2015

49. Hynynen K, Jolesz FA : Demonstration of potential noninvasive ultrasound brain therapy through an intact skull. Ultrasound Med Biol 24 :
275-283, 1998

50. Hynynen K, McDannold N, Vykhodtseva N, Jolesz FA : Noninvasive MR imaging-guided focal opening of the blood-brain barrier in rabbits. Radiology 220 : 640-646, 2001

51. Hynynen K, McDannold N, Vykhodtseva N, Raymond S, Weissleder R, Jolesz FA, et al. : Focal disruption of the blood-brain barrier due to 260 kHz ultrasound bursts: a method for molecular imaging and targeted drug delivery. J Neurosurg 105 : 445-454, 2006

52. Intemann PM, Masterman D, Subramanian I, DeSalles A, Behnke E, Frysinger $R$, et al. : Staged bilateral pallidotomy for treatment of Parkinson disease. J Neurosurg 94 : 437-444, 2001

53. Jalali S, Huang Y, Dumont DJ, Hynynen K : Focused ultrasound-mediated bbb disruption is associated with an increase in activation of AKT: experimental study in rats. BMC Neurol $10: 114,2010$

54. Jeanmonod D, Werner B, Morel A, Michels L, Zadicario E, Schiff G, et al. : Transcranial magnetic resonance imaging-guided focused ultrasound: noninvasive central lateral thalamotomy for chronic neuropathic pain. Neurosurg Focus 32 : E1, 2012

55. Johns LD : Nonthermal effects of therapeutic ultrasound: the frequency resonance hypothesis. J Athl Train 37 : 293-299, 2002

56. Jordão JF, Ayala-Grosso CA, Markham K, Huang Y, Chopra R, McLaurin J, et al. : Antibodies targeted to the brain with image-guided focused ultrasound reduces amyloid-beta plaque load in the TgCRND8 mouse model of Alzheimer's disease. PLoS One 5 : e10549, 2010

57. Jordão JF, Thévenot E, Markham-Coultes K, Scarcelli T, Weng YQ, Xhima $K$, et al. : Amyloid-beta plaque reduction, endogenous antibody delivery and glial activation by brain-targeted, transcranial focused ultrasound. Exp Neurol $248: 16-29,2013$

58. Jung HH, Kim SJ, Roh D, Chang JG, Chang WS, Kweon EJ, et al. : Bilateral thermal capsulotomy with MR-guided focused ultrasound for patients with treatment-refractory obsessive-compulsive disorder: a proof-ofconcept study. Mol Psychiatry 20 : 1205-1211, 2015

59. Kang JY, Wu C, Tracy J, Lorenzo M, Evans J, Nei M, et al. : Laser interstitial thermal therapy for medically intractable mesial temporal lobe epilepsy. Epilepsia 57 : 325-334, 2016

60. Kelly D : Psychosurgery and the limbic system. Postgrad Med J 49 : 825-833, 1973

61. Kennedy JE : High-intensity focused ultrasound in the treatment of solid tumours. Nat Rev Cancer 5 : 321-327, 2005

62. Kim M, Kim CH, Jung HH, Kim SJ, Chang JW : Treatment of major depressive disorder via magnetic resonance-guided focused ultrasound surgery. Biol Psychiatry 83 : e17-e18, 2018

63. Kim SJ, Roh D, Jung HH, Chang WS, Kim CH, Chang JW : A study of novel bilateral thermal capsulotomy with focused ultrasound for treatment-refractory obsessive-compulsive disorder: 2-year follow-up. J Psychiatry Neurosci 43 : 170188, 2018

64. Kinoshita M, McDannold N, Jolesz FA, Hynynen K : Noninvasive localized delivery of Herceptin to the mouse brain by MRI-guided focused ultrasound-induced blood-brain barrier disruption. Proc Natl Acad Sci U S A 103 : 11719-11723, 2006

65. Kinoshita M, McDannold N, Jolesz FA, Hynynen K : Targeted delivery of 
antibodies through the blood-brain barrier by MRI-guided focused ultrasound. Biochem Biophys Res Commun 340 : 1085-1090, 2006

66. Kovacs Z, Werner B, Rassi A, Sass JO, Martin-Fiori E, Bernasconi M : Prolonged survival upon ultrasound-enhanced doxorubicin delivery in two syngenic glioblastoma mouse models. J Control Release 187 : 74-82, 2014

67. Lee MS, Marsden CD : Movement disorders following lesions of the thalamus or subthalamic region. Mov Disord 9 : 493-507, 1994

68. Lee W, Kim H, Jung Y, Song IU, Chung YA, Yoo SS : Image-guided transcranial focused ultrasound stimulates human primary somatosensory cortex. Sci Rep 5 : 8743, 2015

69. Leinenga G, Götz J : Scanning ultrasound removes amyloid- $\beta$ and restores memory in an Alzheimer's disease mouse model. Sci Transl Med $7: 278$ ra233, 2015

70. Li L, Xu B, Zhu Y, Chen L, Sokabe M, Chen L : DHEA prevents Abeta2535-impaired survival of newborn neurons in the dentate gyrus through a modulation of PI3K-Akt-mTOR signaling. Neuropharmacology 59 : 323-333, 2010

71. Lipsman N, Meng Y, Bethune AJ, Huang $Y$, Lam B, Masellis $M$, et al. : Blood-brain barrier opening in Alzheimer's disease using MR-guided focused ultrasound. Nat Commun 9 : 2336, 2018

72. Lipsman N, Schwartz ML, Huang Y, Lee L, Sankar T, Chapman M, et al. : MR-guided focused ultrasound thalamotomy for essential tremor: a proof-of-concept study. Lancet Neurol 12 : 462-468, 2013

73. Liu HL, Hua MY, Chen PY, Chu PC, Pan CH, Yang HW, et al. : Bloodbrain barrier disruption with focused ultrasound enhances delivery of chemotherapeutic drugs for glioblastoma treatment. Radiology 255 : 415-425, 2010

74. Liu HL, Hua MY, Yang HW, Huang CY, Chu PC, Wu JS, et al. : Magnetic resonance monitoring of focused ultrasound/magnetic nanoparticle targeting delivery of therapeutic agents to the brain. Proc Natl Acad Sci U S A 107 : 15205-15210, 2010

75. MacDonell J, Patel N, Rubino S, Ghoshal G, Fischer G, Burdette EC, et al. : Magnetic resonance-guided interstitial high-intensity focused ultrasound for brain tumor ablation. Neurosurg Focus 44 : E11, 2018

76. Magara A, Bühler R, Moser D, Kowalski M, Pourtehrani P, Jeanmonod D : First experience with MR-guided focused ultrasound in the treatment of Parkinson's disease. J Ther Ultrasound 2 : 11, 2014

77. Martínez-Fernández R, Rodríguez-Rojas R, Del Álamo M, HernándezFernández F, Pineda-Pardo JA, Dileone $M$, et al. : Focused ultrasound subthalamotomy in patients with asymmetric Parkinson's disease: a pilot study. Lancet Neurol 17 : 54-63, 2018

78. McDannold N, Arvanitis CD, Vykhodtseva N, Livingstone MS : Temporary disruption of the blood-brain barrier by use of ultrasound and microbubbles: safety and efficacy evaluation in rhesus macaques. Cancer Res 72 : 3652-3663, 2012

79. McDannold N, Clement GT, Black P, Jolesz F, Hynynen K : Transcranial magnetic resonance imaging- guided focused ultrasound surgery of brain tumors: initial findings in 3 patients. Neurosurgery 66 : 323332; discussion 332, 2010

80. McDannold N, Vykhodtseva N, Raymond S, Jolesz FA, Hynynen K : MRI- guided targeted blood-brain barrier disruption with focused ultrasound: histological findings in rabbits. Ultrasound Med Biol 31 : 1527-1537, 2005

81. McDannold NJ, Vykhodtseva NI, Hynynen K : Microbubble contrast agent with focused ultrasound to create brain lesions at low power levels: MR imaging and histologic study in rabbits. Radiology 241 : 95 106, 2006

82. Meng Y, Suppiah S, Mithani K, Solomon B, Schwartz ML, Lipsman N : Current and emerging brain applications of MR-guided focused ultrasound. J Ther Ultrasound $5:$ 26, 2017

83. Meyers R, Fry WJ, Fry FJ, Dreyer LL, Schultz DF, Noyes RF : Early experiences with ultrasonic irradiation of the pallidofugal and nigral complexes in hyperkinetic and hypertonic disorders. J Neurosurg 16 : 32-54, 1959

84. Monteith S, Sheehan J, Medel R, Wintermark M, Eames M, Snell J, et al. : Potential intracranial applications of magnetic resonance-guided focused ultrasound surgery. J Neurosurg 118 : 215-221, 2013

85. Monteith SJ, Harnof S, Medel R, Popp B, Wintermark M, Lopes MB, et al. : Minimally invasive treatment of intracerebral hemorrhage with magnetic resonance-guided focused ultrasound. J Neurosurg 118 : 10351045, 2013

86. Morris CE, Juranka PF : Nav channel mechanosensitivity: activation and inactivation accelerate reversibly with stretch. Biophys J 93 : 822-833, 2007

87. Na YC, Chang WS, Jung HH, Kweon EJ, Chang JW : Unilateral magnetic resonance-guided focused ultrasound pallidotomy for Parkinson disease. Neurology 85 : 549-551, 2015

88. Naor O, Krupa S, Shoham S : Ultrasonic neuromodulation. J Neural Eng $13: 031003,2016$

89. Niranjan A, Raju SS, Kooshkabadi A, Monaco E 3rd, Flickinger JC, Lunsford LD : Stereotactic radiosurgery for essential tremor: retrospective analysis of a 19-year experience. Mov Disord 32 : 769-777, 2017

90. Niu J, Xie J, Guo K, Zhang X, Xia F, Zhao X, et al. : Efficient treatment of Parkinson's disease using ultrasonography-guided rhFGF20 proteoliposomes. Drug Deliv 25 : 1560-1569, 2018

91. Nyborg WL : Acoustic streaming. San Diego : Academic Press, 1998, pp207-231

92. O'Brien WD Jr : Ultrasound-biophysics mechanisms. Prog Biophys Mol Biol 93 : 212-255, 2007

93. Pardridge WM : Blood-brain barrier drug targeting: the future of brain drug development. Mol Interv 3 : 90-105, 151, 2003

94. Pardridge WM : The blood-brain barrier: bottleneck in brain drug development. NeuroRx 2 : 3-14, 2005

95. Park EJ, Zhang YZ, Vykhodtseva N, McDannold N : Ultrasound-mediated blood-brain/blood-tumor barrier disruption improves outcomes with trastuzumab in a breast cancer brain metastasis model. J Control Release $163:$ 277-284, 2012

96. Patel DM, Walker HC, Brooks R, Omar N, Ditty B, Guthrie BL : Adverse events associated with deep brain stimulation for movement disorders: analysis of 510 consecutive cases. Neurosurgery 11 Suppl 2 : 190 199, 2015 
97. Ravikumar VK, Parker JJ, Hornbeck TS, Santini VE, Pauly KB, Wintermark $M$, et al. : Cost-effectiveness of focused ultrasound, radiosurgery, and DBS for essential tremor. Mov Disord 32 : 1165-1173, 2017

98. Raymond SB, Treat LH, Dewey JD, McDannold NJ, Hynynen K, Bacskai $\mathrm{BJ}$ : Ultrasound enhanced delivery of molecular imaging and therapeutic agents in Alzheimer's disease mouse models. PLoS One 3 : e2175, 2008

99. Reher P, Doan N, Bradnock B, Meghji S, Harris M : Effect of ultrasound on the production of IL-8, basic FGF and VEGF. Cytokine 11 : 416-423, 1999

100. Rezayat $E$, Toostani IG : A review on brain stimulation using low intensity focused ultrasound. Basic Clin Neurosci 7 : 187-194, 2016

101. Scarcelli T, Jordão JF, O'Reilly MA, Ellens N, Hynynen K, Aubert I : Stimulation of hippocampal neurogenesis by transcranial focused ultrasound and microbubbles in adult mice. Brain Stimul 7 : 304-307, 2014

102. Schlesinger I, Eran A, Sinai A, Erikh I, Nassar M, Goldsher D, et al. : MRI guided focused ultrasound thalamotomy for moderate-to-severe tremor in Parkinson's disease. Parkinsons Dis 2015 : 219149, 2015

103. Scoville WB : Selective cortical undercutting as a means of modifying and studying frontal lobe function in man; preliminary report of 43 operative cases. J Neurosurg 6 : 65-73, 1949

104. Sheikov N, McDannold N, Sharma S, Hynynen K : Effect of focused ultrasound applied with an ultrasound contrast agent on the tight junctional integrity of the brain microvascular endothelium. Ultrasound Med Biol 34 : 1093-1104, 2008

105. Sheikov N, McDannold N, Vykhodtseva N, Jolesz F, Hynynen K : Cellular mechanisms of the blood-brain barrier opening induced by ultrasound in presence of microbubbles. Ultrasound Med Biol 30 : 979-989, 2004

106. Shung KK, Smith M, Tsui BMW : Principles of Medical Imaging. Oxford : Elsevier Science, 1992

107. Siegel KL, Metman LV : Effects of bilateral posteroventral pallidotomy on gait of subjects with Parkinson disease. Arch Neurol 57 : 198-204, 2000

108. Sillay KA, Larson PS, Starr PA : Deep brain stimulator hardware-related infections: incidence and management in a large series. Neurosurgery 62 : 360-366; discussion 366-367, 2008

109. Sprawls $P$ : Physical Principles of Medical Imaging. Rockville: Aspen, 1987

110. Szabo T : Diagnostic Ultrasound Imaging Inside Out. Amsterdam : Elsevier Academic, 2004

111. Tasker RR : Deep brain stimulation is preferable to thalamotomy for tremor suppression. Surg Neurol 49 : 145-153; discussion 153-154, 1998

112. ter Haar $\mathrm{G}$ : Therapeutic applications of ultrasound. Prog Biophys Mol Biol 93 : 111-129, 2007

113. Thévenot E, Jordão JF, O'Reilly MA, Markham K, Weng YQ, Foust KD, et al. : Targeted delivery of self-complementary adeno-associated virus serotype 9 to the brain, using magnetic resonance imaging-guided focused ultrasound. Hum Gene Ther 23 : 1144-1155, 2012
114. Timbie KF, Afzal U, Date A, Zhang C, Song J, Wilson Miller G, et al. : MR image-guided delivery of cisplatin-loaded brain-penetrating nanoparticles to invasive glioma with focused ultrasound. J Control Release 263 : 120-131, 2017

115. Treat LH, McDannold N, Vykhodtseva N, Zhang Y, Tam K, Hynynen K : Targeted delivery of doxorubicin to the rat brain at therapeutic levels using MRI-guided focused ultrasound. Int J Cancer 121 : 901-907, 2007

116. Treat LH, McDannold N, Zhang Y, Vykhodtseva N, Hynynen K : Improved anti-tumor effect of liposomal doxorubicin after targeted blood-brain barrier disruption by MRI-guided focused ultrasound in rat glioma. UItrasound Med Biol 38 : 1716-1725, 2012

117. Tufail Y, Matyushov A, Baldwin N, Tauchmann ML, Georges J, Yoshihiro A, et al. : Transcranial pulsed ultrasound stimulates intact brain circuits. Neuron 66 : 681-694, 2010

118. Tyler WJ : Noninvasive neuromodulation with ultrasound? A continuum mechanics hypothesis. Neuroscientist $17:$ 25-36, 2011

119. Tyler WJ, Tufail Y, Finsterwald M, Tauchmann ML, Olson EJ, Majestic C : Remote excitation of neuronal circuits using low-intensity, low-frequency ultrasound. PLoS One 3 : e3511, 2008

120. Vykhodtseva N, McDannold N, Hynynen K : Progress and problems in the application of focused ultrasound for blood-brain barrier disruption. Ultrasonics 48 : 279-296, 2008

121. Vykhodtseva NI, Hynynen K, Damianou C : Histologic effects of high intensity pulsed ultrasound exposure with subharmonic emission in rabbit brain in vivo. Ultrasound Med Biol 21 : 969-979, 1995

122. Wei KC, Chu PC, Wang HY, Huang CY, Chen PY, Tsai HC, et al. : Focused ultrasound-induced blood-brain barrier opening to enhance temozolomide delivery for glioblastoma treatment: a preclinical study. PLoS One 8 : e58995, 2013

123. Weigel R, Krauss JK : Center median-parafascicular complex and pain control. Review from a neurosurgical perspective. Stereotact Funct Neurosurg 82 : 115-126, 2004

124. Yang FY, Wong TT, Teng MC, Liu RS, Lu M, Liang HF, et al. : Focused ultrasound and interleukin-4 receptor-targeted liposomal doxorubicin for enhanced targeted drug delivery and antitumor effect in glioblastoma multiforme. J Control Release 160 : 652-658, 2012

125. Yao L, Song Q, Bai W, Zhang J, Miao D, Jiang M, et al. : Facilitated brain delivery of poly (ethylene glycol)-poly (lactic acid) nanoparticles by microbubble-enhanced unfocused ultrasound. Biomaterials 35 : 33843395, 2014

126. Young RF, Vermeulen SS, Grimm P, Posewitz AE, Jacques DB, Rand RW, et al. : Gamma Knife thalamotomy for the treatment of persistent pain. Stereotact Funct Neurosurg 64 Suppl 1 : 172-181, 1995

127. Yu H, Neimat JS : The treatment of movement disorders by deep brain stimulation. Neurotherapeutics 5 : 26-36, 2008

128. Zaaroor M, Sinai A, Goldsher D, Eran A, Nassar M, Schlesinger I : Magnetic resonance-guided focused ultrasound thalamotomy for tremor: a report of 30 Parkinson's disease and essential tremor cases. J Neurosurg $128: 202-210,2018$ 